\title{
RECONHECIMENTO DE DIREITOS DE PESSOAS TRANS: ALTERNATIVAS, POLÍTICAS E ATIVISMO TEÓRICO-JUDICIAL
}

\author{
RECOGNITION OF TRANS PEOPLE RIGHTS: ALTERNATIVES, POLICIES AND \\ THEORETICAL-JUDICIAL ACTIVISM
}

\section{Vinicius Ferreira Baptista}

Doutor em Políticas Públicas. Professor adjunto do Departamento de Administração Pública e do Programa de Pós-graduação em Desenvolvimento Territorial e Políticas Públicas da Universidade Federal Rural do Rio de Janeiro (UFRRJ).

E-mail: viniciusferbap2007@hotmail.com

Recebido em: $14 / 11 / 2020$

Aprovado em: 24/04/2021

RESUMO: A luta de pessoas trans ao reconhecimento de direitos vem ganhando substancialidade na segunda metade do século XX no Brasil. Da negligência de direitos ou o não reconhecimento explícito dos mesmos, uma série de litígios alcançaram a Suprema Corte no país. Neste sentido, o objeto deste trabalho é analisar as decisões proferidas destes litígios à luz da compreensão teórica de gênero à luz das interpretações que orientaram as mesmas. Avaliamos, por Análise de Conteúdo, decisões do Supremo Tribunal Federal no Brasil e pela Suprema Corte dos Estados Unidos. Procuramos demonstrar a responsabilidade civil objetiva do Poder Público de efetivar direitos, quando sujeitos indicam não serem considerados de igual valor moral na sociedade. Esta reivindicação não pode ser confundida com a criação de "novos" direitos. Ao mesmo tempo, não se trata de um "ativismo judicial" que colocaria o Poder Judiciário em contexto criador de leis. Todavia, há de se considerar o papel limitante do Judiciário, não sendo considerado como capaz de reescrever direitos e promover mudanças sociais, mesmo com negligência do Executivo ou Legislativo. Por outro lado, nesta flagrante desconsideração de direitos, é por via judiciária que ocorre efetivação de direitos, ainda mais quando evidenciados o alto grau de vulnerabilidade dos grupos sociais afetados. É preciso, portanto, que a interpretação de conceitos seja à luz de como valores políticos afetam a estrutura normativa, assim, a compressão e concepção de Justiça, Democracia e Dignidade Humana não são conflitantes, nem autônomos, mas analisados e interpretados de perspectiva integrada.

Palavras-chave: Pessoas transgêneras. Pessoas transexuais. Direitos. Gênero. Direitos Humanos.

ABSTRACT: The struggle of trans people to recognize rights has been gaining substantiality in the second half of the 20th century in Brazil. From the neglect of rights or the explicit lack of recognition of them, a series of disputes reached the Supreme Court in the country. In this sense, the object of this work is to analyze the decisions rendered in these disputes in the light of the theoretical understanding of gender in the light of the interpretations that guided them. We assessed, through Content Analysis, decisions of the Supreme Court in Brazil and the Supreme Court of the United States. We seek to demonstrate the objective civil liability of the Public Power 
to enforce rights, when subjects indicate that they are not considered of equal moral value in society. We should not confuse this claim with the creation of "new" rights. At the same time, this is not a "judicial activism" that would place the Judiciary in a law-creating context. However, we must consider the limiting role of the Judiciary, not being considered as capable of rewriting rights and promoting social changes, even with the negligence of the Executive or Legislative. On the other hand, in this flagrant disregard of rights, it is through the judicial system that rights are enforced, especially when the high degree of vulnerability of the affected social groups is evidenced. Therefore, it is necessary that the interpretation of concepts is in the light of how political values affect the normative structure, thus, the compression and conception of Justice, Democracy and Human Dignity are not conflicting, nor autonomous, but analyzed and interpreted in an integrated perspective.

Keywords: Transgender people. Transsexual people. Rights. Gender. Human rights.

SUMÁRIO: Introdução. 1 Contra a violência, o estigma e a desigualdade: por uma agenda de direitos e direitos a serem exercidos. 2 Transativismo judiciário e a disputa na mobilização social e política. 3 Um paralelo quanto ao direito de pessoas transexuais e transgêneros na suprema corte norte americana. 4 As decisões no Supremo Tribunal Federal. 4.1 Ação direta de inconstitucionalidade 4.275 Distrito Federal de 2009 e Recurso Extraordinário 670.422 Rio Grande do Sul de 2012. 4.2 Ação Direta de Inconstitucionalidade por Omissão 26 Distrito Federal de 2013. 4.3 Habeas Corpus 152.491 São Paulo de 2018. 4.4 Medida Cautelar na Arguição de Descumprimento de Preceito Fundamental 527 Distrito Federal. 4.5 Recurso Extraordinário 845.779 Rio Grande do Sul de 2014. 5 Mobilizando gênero na compreensão sociojurídica. Considerações Finais. Referências.

\section{INTRODUÇÃO}

O objeto deste trabalho é analisar as decisões proferidas destes litígios à luz da compreensão teórica de gênero à luz das interpretações que orientaram as mesmas. Assim, considerando que decisões judiciais mobilizam categorias para interpretação, nos indagamos em compreender como decisões do Supremo Tribunal Federal no Brasil e pela Suprema Corte dos Estados Unidos resolvem os litígios referentes à reivindicação de direitos por pessoas trans (que podem abranger Transgêneros, Transexuais e Travestis, este último em discussões na corte brasileira). Metodologicamente, analisamos, por Análise de Conteúdo, acórdãos de seis decisões pelo Supremo Tribunal Federal e um acórdão referente a três processos em pauta na Corte Suprema dos Estados Unidos.

Nas duas primeiras partes, nos propusemos a articular concepções teóricas e normativas que circundam a violência, o estigma e a desigualdade na luta por direitos de pessoas trans e como estes contextos são articulados política, social e juridicamente por movimentos e pessoas trans. $\mathrm{Na}$ terceira a quinta partes, analisamos as decisões das Cortes Supremas do Brasil e Estados Unidos, categorizando conceitos e demonstrando movimentos teóricos e sóciojurídicos articulados pelos juízes em duas decisões. Por fim, apresentamos nossas considerações finais.

Procuramos demonstrar, com este trabalho, a responsabilidade civil objetiva do Poder Público de efetivar direitos, quando sujeitos indicam claramente não serem considerados de igual valor moral na sociedade. Afastamos a concepção de que este processo crie "novos" direitos, assim como ou se configure como "ativismo judicial". Entendemos, assim, que se trata de leitura moral abrangente de regras a permitir que direitos, já usufruídos pela maioria da população, seja exercido por aqueles excluídos na concepção original das normativas.

Ressaltamos o limite do Poder Judiciário em reescrever direitos e promover mudanças sociais, mesmo em flagrante omissão e negligência do Executivo ou Legislativo. Contudo, é nesta 
flagrante desconsideração de direitos, que o Poder Judiciário assume responsabilidade quanto à efetivação de direitos.

\section{CONTRA A VIOLENCIA, O ESTIGMA E A DESIGUALDADE: POR UMA AGENDA DE DIREITOS E DIREITOS A SEREM EXERCIDOS}

A transgeneridade, a transexualidade e o travestismo eram considerados pela comunidade médica, por meio da décima Classificação Estatística Internacional de Doenças e Problemas Relacionados com a Saúde (CID-10) como "Transtornos da identidade sexual"1, compreendendo quatro transtornos: Transexualismo, Travestismo bivalente, Transtorno de identidade sexual na infância, outros transtornos da identidade sexual e Transtorno não especificado da identidade sexual. Em 18 de junho de 2018, a Organização Mundial da Saúde publicou a décima primeira edição do CID, retirando o "transexualismo" do catálogo de doenças mentais e inserida como "incongruência de gênero", no capítulo intitulado como "condições relacionadas à saúde sexual"2. A incongruência de gênero é caracterizada por uma incongruência marcante e persistente entre uma experiência de gênero de um indivíduo e seu sexo assinalado. Apenas a variação comportamental de gênero e preferências são insuficientes para diagnosticar este processo. Cada país terá até $1^{\circ}$ de janeiro de 2022 para se adaptar à nova CID.

A transgeneridade é processo afetado por representações de transgêneros em vários veículos que incidem forte papel nas narrativas ampliadas de identidades não mais definíveis em "grandes identidades" que marcariam o gênero e a sexualidade, agora vistos no plural, gêneros e sexualidades, desafiando dualidades masculino-feminino e as biologizações teóricas, desestabilizando categorias. A "fluidez", para Phillips (2006), se torna o maior desafio, sob o ponto de vista sociocultural e político em décadas por esta redefinição posta.

$\mathrm{O}$ corpo e a performance se tornam elementos críticos no enfrentamento às rígidas concepções sociais, legais, morais e culturais que orientam, inclusive, os direitos, quando associados às dimensões de papel. O transexual, neste aspecto, é confundido e resumido a alguém que necessariamente passou por redesignação sexual (interpretada geralmente pela cirurgia) como definição de seu gênero. Neste ponto, o transexual é alguém em contexto pré ou pós processo de redesignação sexual, que pode ou não envolver a cirurgia de mudança de sexo. Já o transgênero, aponta Berg-Weger (2006) é alguém que flui em sua concepção de identidade de gênero, geralmente diferente das expectativas típicas do seu sexo atribuído ao nascer.

A reivindicação de direitos a partir de experiências trans no Brasil assumiu, ao menos a partir da década de 1990, um entrelaçamento de novos processos identitários capazes de reconfigurar disposições conceituais e representativos sobre individualidades subjetivas. Stefanes Pacheco \& Pacheco (2016, p. 205) ressurgiram "exigindo seus direitos enquanto sujeitos de direitos". Para as autoras, o discurso jurídico é permeado por "verdades" que conjugam poderes específicos, os quais, no caso de pessoas transexuais e trangêneros, aliam-se aos discursos médicos, cuja constituição biológica naturaliza como "verdade" irrefutável uma concepção social.

Peres (2001) situa o sexo morfológico, sexo de criação e sexo psicossocial, passando de uma concepção meramente biológica, para contemplar componentes genéticos, endócrinos, morfológicos, civis e psíquicos. Para a autora, pode existir compatibilidade entre sexo biológico, legal e de criação, contudo, "pode haver uma incompatibilidade entre a identidade de gênero e o sexo de criação, tendo em vista a concepção de sexo psicossocial” (PERES, 2001, p. 278), logo, podem existir casos em que o sexo psicossocial se incompatibiliza com o sexo biológico.

Neste sentido, quando um indivíduo se coloca em conflito o qual, acaba por desloca-lo das interpretações usuais de sexo e gênero, a questão do direito à resolução do conflito emerge,

\footnotetext{
${ }^{1}$ Ver a lista completa em https://icd.who.int/browse10/2019/en\#/F64. Acesso em 29 de outubro de 2020.

2 Ver a lista em https://icd.who.int/browse11/l-m/en\#/http\%3a\%2f\%2fid.who.int\%2ficd\%2fentity\%2f411470068. Acesso em 29 de outubro de 2020.
}

Revista de Direito Brasileira | Florianópolis, SC | v. 28 | n. 11 | p.131-163 | Jan./Abr. 2021 
tornando uma situação não apenas moral, assim como política e de princípios, envolvendo concepções de justiça, igualdade, valor e liberdade. A agenda de direitos no tocante às reivindicações de pessoas trans, assim, demarcam uma nova compreensão sobre sexo e gênero que irão igualmente delimitar as fronteiras de justiça na demanda de direitos, ou então, a sua efetivação para um grupo marginalizado.

Amaral et al (2014) entendem que é a partir da década de 1990 que ocorreu "um crescente e produtivo interesse de pesquisadores pelo tema na seara dos estudos de gênero e sexualidades", inicialmente pensado na lógica saúde-doença assim como o acesso aos serviços de saúde pública, sobretudo em relação ao processo transexualizador no âmbito do Sistema Único de Saúde (SUS) ${ }^{3}$. Posteriormente é que se passa a construir conhecimento acerca das reivindicações de pessoas trans. Ao mesmo tempo, Conselho de Direitos Humanos da ONU, em 2006, por intermédio dos Princípios de Yogyakarta, delimitam como essencial o respeito pelas nações à identidade de gênero de seus cidadãos, afim de que se expressem sem constrangimentos, o que delimita tratamento igual entre as pessoas e a igualdade de direitos (BRASIL, 2017).

Estes processos constitutivos de verdades engendram relações de poder que delimitam direitos, deveres e indicam sujeitos de direitos, ao passo em que também delimitam os excluídos, ou os indignos. Tal processo perpassa, inclusive, a constituição do Estado Brasileiro em termos de sujeitos de direitos, os quais, marginalizados na esfera pública de reconhecimento enquanto membros da comunidade política com iguais liberdades, direitos e deveres, passam a organizar-se em grupos e movimentos sociopolíticos na reivindicação de que tenham direitos. Esta reivindicação, todavia, assume uma perspectiva diferente, do ponto de vista analítico. Trata-se de, primeiramente, no caso de pessoas transexuais, transgêneros e travestis, de uma trajetória de direito a ter direitos, a exemplo da percepção de Hannah Arendt (1979). Uma trajetória em que a luta política é a de ser considerados sujeitos que devem ser reconhecidos como políticos e membros da comunidade. É, portanto, a luta contra a deliberada exclusão chancelada pelo não reconhecimento do Estado.

A construção desta luta situa "a existência de cidadãos e cidadãs que não correspondem ao papel social que lhes foi atribuído", notadamente, papeis associados à heteronormatividade que divide o gênero em formas binárias como homem-mulher ou macho-fêmea (STEFANES PACHECO \& PACHECO, 2016, p. 207). Qualquer “desvio" é considerado uma desvalorização de normas e condutas, as quais devem ser punidas (violentamente ou não), marginalizadas (pela estigmatização) e marginalizadas (pela exclusão legal, política, social e econômica). Stefanes Pacheco \& Pacheco (2016, p. 209) indicam que estas construções que erguem as exclusões se pautam na visão essencialista sobre gênero e sexualidade, que "enfatiza a heterossexualidade como algo normal e superior, considerando as demais formas de sexualidades como desviantes e inferiores". Ao mesmo tempo, dão ênfase ao papel masculino e à sua representação social.

Esta matriz heterossexual compulsória normaliza situações, identidades e aponta a anormalidade, inclusive, de pessoas. Os ditos "anormais" são estigmatizados e caracterizados não apenas como "desviantes", mas defeituosos em sentido moral (BUTLER, 1999). Esta anormalidade instituída passa a requerer que os "anormais" sejam expulsos e afastados socialmente, daí se decorre a violência simbólica que pode resultar na violência material (BOURDIEU, 2001). Como apontam Stefanes Pacheco \& Pacheco (2016, p. 210), "é por meio da incorporação e naturalização do modelo binário de gênero que a violência simbólica atua nos(as) transexuais", os instituindo como grupos socialmente vulneráveis às sequelas orgânicas e emocionais, derivadas da violência.

As normas de gênero produzem um conflito na experiência identitária de transexuais (BENTO, 2010), não apenas por elementos estritamente psicológicos, mas também corporais, em que as genitálias são lidas conforme o gênero, criando expectativas, ideologias e comportamentos sociais (CHANTER, 2007). Este complexo processo formador de matrizes culturais expõe a

${ }^{3}$ Direito assegurado pela Portaria n. 457, de 19 de agosto de 2008.

Revista de Direito Brasileira | Florianópolis, SC | v. 28 | n. 11 | p.131-163 | Jan./Abr. 2021 
identidade de gênero compreensível como a ser seguida, valorizando experiências, rebaixando outras e instituindo marcadores sociais de rebaixamento, evidenciando os indesejáveis (BUTLER, 1999).

Estes marcos de violência ferem a dignidade da pessoa humana, um fundamento da Constituição Federal brasileira (art. $1^{\circ}$, inc. III, CFRB), atingindo a inviolabilidade da intimidade e da honra das pessoas (art. $5^{\circ}$, inc. X, CFRB), pois a identificação sexual, é parte constituinte do direito à personalidade (que engloba intimidade e corpo), sendo irrenunciável e intransmissível. Igualmente, autonomia e autodeterminação orientam os indivíduos que são reivindicados por transexuais e transgêneros em uma série de ações e movimentos, como sujeitos plenos de direitos civis. A despeito disso, o direito de pessoas trans a realizarem alterações em seu registro civil, modificando o gênero e prenome é uma configuração de discriminação. Mais: esta discriminação é realizada pelo Estado.

Até o ano de 2018, quando foram julgadas pelo Supremo Tribunal Federal, em conjunto, o Recurso Extraordinário 670.422 e Ação Direta de Inconstitucionalidade 4.275, a alteração do gênero e do prenome no Registro Civil era realizado apenas via autorização judicial, o que deixava a decisão à orientação do juiz na análise do caso, o qual poderia deferir em primeira instância, mas ter revogado na segunda. A questão se dá pela fragilidade da dependência aos arranjos jurídicos. Existe o Projeto de Lei n. 5002/13, que estabelece o direito à identidade de gênero ${ }^{4}$, colocando o Estado, via Sistema Único de Saúde e planos de saúde, como fiadores do tratamento de alteração de sexo, assim como, no lado jurídico, libera a mudança do prenome para os maiores de 18 anos, sem necessidade de autorização judicial, ao passo em que desobriga a redesignação sexual desta. O projeto esteve parado entre 2015 e 2018 em comissões, obtendo pareceres favoráveis, contudo, por pressões de bancadas foi arquivado em 2019 por não votação.

A questão do nome social, por conta do Decreto $n^{\circ} 8.727$ publicado no Diário Oficial da União em 29 de abril de 2016, é analisada sob um viés contendo um risco de reduzir a identidade de gênero ao nome social por ser insuficiente em dar conta das demandas da população trans, que reivindicam direitos tanto civis quanto derivados do primeiro (BENTO, 2010). Ou seja, reduzir esta identidade é impedir as pessoas trans como sujeitos de direitos plenos que possuem apenas um direito que não é suficientemente capaz de derivar outros direitos relacionados aos direitos civis ${ }^{5}$.

Cortes (2019) delimita uma série de ações afim de solucionar os problemas que envolvem, em parte, a questão do direito ao registro civil por pessoas trans, citando como exemplos: 1) a Ação Direta de Inconstitucionalidade n⿳ 4.275 , proposta em 2009 pela Procuradoria Geral da República; 2) o Recurso Extraordinário $n^{\circ} 670.4229$ originário do Rio Grande do Sul e protocolado em 2012, cuja repercussão geral foi reconhecida pelo Supremo Tribunal Federal em setembro de 2014; 3) o Recurso Especial 1.626.739 do Rio Grande do Sul julgado procedente pelo Superior Tribunal de Justiça em 2017 e; 4) o PL 5002/2013 já citado.

Pesquisa realizada por Cortes (2019), no que se refere a 111 acórdãos do Tribunal de Justiça de São Paulo (TJSP), dentre as quais as pessoas que solicitam alteração do prenome, 42\% das pessoas transexuais obtiveram decisões favoráveis, enquanto que $52 \%$ das pessoas cisgêneras tiveram sucesso. Ao mesmo tempo, o número de casos decididos pelo TJSP envolvendo pessoas cisgêneras que procuram o Judiciário para alterar o prenome é consideravelmente maior. Quanto à motivação, se percebe a visão medicalizante sobre a transgeneridade na argumentação de pessoas trans e a ausência de cirurgia de transgenitalização ${ }^{6}$ como argumento para negar a alteração de prenome.

\footnotetext{
${ }^{4}$ Definida como "vivência interna e individual do gênero tal como cada pessoa o sente, que pode corresponder ou não com o sexo atribuído após o nascimento"

${ }^{5}$ Isso não significa que mesmo que este direito apregoado pelo decreto sobre o nome social seja respeitado. De acordo com Cortes (2019), o autor aponta uma série de casos de desrespeito ao uso do nome social.

${ }^{6}$ Caso a cirurgia de transgenitalização não tenha sido realizada, apenas $24 \%$ das pessoas interessadas tiveram decisões favoráveis (CORTES, 2019, p. 116).
} 
Quando nos referimos à dupla violência que pessoas trans sofrem, tanto de pessoas, quanto do Estado, Cortes (2019, p. 119-120) traz uma informação que demonstra este processo, apontando que "que o inconformismo do Ministério Público atinge até mesmo os casos em que a cirurgia de transgenitalização foi realizada [...] colocando como principal requisito para o deferimento a capacidade reprodutiva" ao mesmo tempo em que alega a "a dificuldade que a sociedade tem de entender a transgeneridade". De acordo com a autora, o Ministério Público recorreu em 5\% dos casos de pessoas cisgêneras, enquanto recorreu em $30 \%$ dos casos de pessoas trans. Por fim, a averbação na certidão de nascimento de que a mudança se deu por decisão judicial ocorreu em 50\% dos casos de pessoas trans e apenas $2 \%$ dos casos de pessoas cisgêneras (CORTES, 2019, p. 120121). Para a autora, existe uma discriminação direta na aplicação do direito.

Mello (2018) ressalta o julgamento do Habeas Corpus $n^{\circ} 152.491$ pelo STF como um marco à proteção e promoção do direito de transexuais quando determinou a transferência de duas travestis para uma unidade prisional compatível com suas identidades de gênero. Para a autora, o STF trouxe à baila "aspectos relevantes acerca da discriminação que a população LGBTT sofre dentro do sistema prisional", assim como o prejuízo aos "os princípios da dignidade da pessoa humana e respeito à diversidade [...] decorrentes dos princípios da humanidade ou humanização das penas" (MELLO, 2018, p. 194).

Mello (2018) analisa que as prisões compõem processos que repartem indivíduos, tirando seu tempo e forças, alterando seu comportamento, mantidos em plena vigilância, considerando que "o controle sobre o corpo e a sexualidade na prisão reflete a desigualdade de gênero existente na sociedade", sofrendo maior intensidade de violência e exposição por conta disso. Ao mesmo tempo, "o direito penal não diferencia entre homens e mulheres ou transexuais e travestis em suas normas", o sistema prisional o faz, inclusive, desrespeitando o acesso à assistência jurídica.

Dentro do sistema prisional, transexuais e travestis são novamente violentados em seus direitos, sendo vitimadas por espancamentos, mutilações e estupros coletivos (MELLO, 2018). Parece que a previsão de Jeffreys (2014) de que transexuais violentariam mulheres não ocorre, mas o contrário: são transexuais e travestis que sofrem violência quando são alocados em penitenciárias diferentes de suas identidades de gênero. Para Mello (2018), a interpretação usual que se tem, é de que dentro de sistema prisionais não se respeita direitos fundamentais, o que configura violação do Estado Democrático de Direito e afronta aos princípios constitucionais, com claro ataque à dignidade da pessoa humana e seu direito à integridade e personalidade.

Dentro da violência estatal está a ocultação desta violência sofrida por travestis, transexuais e transgêneros no sistema penitenciário brasileiro. Inexiste no Departamento Nacional Penitenciário, estatísticas relativas a este assunto, denotando a descaso público. Oliveira et al (2018, p. 161) destacam que estas pessoas sofrem "Dormir de cabelo comprido e acordar de cabelo raspado", "Ser obrigada a agir como mulas para o tráfico", "Ser obrigada a esconder entorpecentes em cavidades do corpo", "Estupros coletivos", "Agressões corporais", "transmisoginia". Em muitos casos existe requintes de crueldade, pois o corpo transexual é uma afronta até às construções de gênero intraprisionais.

Os contextos que envolvem o assassinato de travestis, transexuais e transgêneros circundam "tentativa de expurgar o corpo de um mal iminente", pelas formas violentas, sádicas e cruéis aplicadas ao modus operandi do crime. Ao mesmo tempo, a objetificação do corpo aponta indica a alta busca pela pornografia (OLIVEIRA et al, 2018, p. 161). Ainda nesta seara, as dimensões sociais, políticas, econômicas, educacionais e de trabalho que desvinculam travestis e transexuais do acesso às dimensões e decorrentes oportunidades, cria um processo de desalento, expulsão e marginalização legal e material na vida das mesmas.

$\mathrm{O}$ medo ronda travestis e transexuais em sistemas prisionais, pois seu direito à personalidade e integridade física não são respeitados, uma vez que a exposição é capaz de vulnerabilizar sua existência. Oliveira et al (2018, p. 165) entendem que neste momento ocorre a 
abjeção, onde se delimita a "escória" da sociedade em que se tem a "maximização das violações sofridas em liberdade", dentre elas "à negação do direito de acesso à hormonização".

Em 2014, pelo Disque 1007, foram realizadas 227 denúncias de violência contra mulheres por elas serem lésbicas, bissexuais ou transexuais (ENGEL, 2020). A questão é que mesmo um programa destinado à violência contra a mulher, como o Disque 100, não capta as mulheres trans, que não são compreendidas, neste sentido, como alvo de uma violência misógina. $O$ obscurecimento de mulheres trans e travestis da proteção legal está na manipulação decorrente do processo legislativo quando da criação da Lei $\mathrm{n}^{\mathbf{0}}$ 13.104, de 9 de março de 2015, a Lei do Feminicídio, que cria este como uma qualificadora do crime de homicídio, tendo em vista crime contra à vida da mulher "por razões da condição de sexo feminino". O termo gênero feminino, que era previsto no anteprojeto da lei, foi substituído pelo termo sexo feminino, associando as mulheres à compreensão biológica. $\mathrm{O}$ afastamento da proteção legal, portanto, é uma forma de violência institucional e legal do Estado, que rebaixa categorias de cidadãos ao desamparo protetivo.

\section{TRANSATIVISMO JUDICIÁRIO E A DISPUTA NA MOBILIZAÇÃo SOCIAL E POLÍTICA}

A reivindicação de direitos para pessoas transgêneros é permeada pela recente teorização sobre um fenômeno concebido como "ativismo judicial", ou seja, quando o Poder Judiciário assume um contorno proativo de incitar debates jurídico-normativos e, sobretudo, de alterações legislativas, acerca de temáticas que são afastadas ou negligenciadas por atores do Poder Legislativo. No caso brasileiro, temos situações em que o Supremo Tribunal Federal (STF) ratificou a morosidade proposital do Congresso Nacional em legislar normativas (que contrariam interesses de bancadas conservadoras que predominam as instâncias legislativas). Neste sentido, é nítido o papel ativista do STF, quando destaca a morosidade do Legislativo e o obriga a legislar.

Para Kmiec (2004), o termo tem origem no pós-guerra de meados do século XX, tendo intensificação a partir da década de 1970 na produção acadêmica e em decisões judiciais nos Estados Unidos. $\mathrm{O}$ autor aponta que o ativismo judicial congrega a inconstitucionalidade como fundamento à invalidação de atos governamentais, considerando, inclusive o desrespeito aos atos precedentes que acabam, ao fim, produzindo novas normas pelo Judiciário, cujo viés de tomada de decisão e interpretação se orientam por resultados. Ressalta Koerner (2013, p. 71) que o foco da questão sobre o ativismo reside na "autonomia dos agentes judiciais no processo de tomada de decisão", assim como "o modelo de decisão e o comportamento ou atitude do juiz apropriados a uma ordem constitucional e democrática". Araújo (2018), também destaca que este fenômeno não é restrito aos Estados Unidos e se alastra por países com base constitucionalista em rodem democrática.

Ainda nesta seara, Koerner (2013) pondera que ativismo judicial pressupõe uma situaçãolimite entre Política e o Direito. Ao ultrapassar estas fronteiras, problema normativo congrega a inadequação do ativismo judicial à Constituição e a democracia, em que juízes passariam a elaborar leis e não apenas interpretá-la. Por outro lado, Miarelli e Lima (2012) enfatizam um novo papel dos juízes em não apenas interpretar leis, mas torná-las efetivas na prática, considerando contexto derivado da inoperância dos outros poderes e omissão patológica do Poder Legislativo.

O ativismo judicial engendra o que Tate e Vallinder (1995) consideram como orientações elaboradas pelo juiz para contradizer a política majoritária vigente que interpreta determinada situação naquele momento. Esta contrariedade marca o início do ativismo, o qual, quando marcado

\footnotetext{
${ }^{7}$ O Disque 100 é um serviço disseminação de informações sobre direitos de grupos vulneráveis e de denúncias de violações de direitos humanos. Existe também a Central de Atendimento à Mulher em Situação de Violência - Ligue 180, nos mesmos moldes, mas direcionado às mulheres para denunciar violência de gênero. Ver o Disque 100 em: https://www.gov.br/mdh/pt-br/acesso-a-informacao/disque-100-1. E o Ligue 180 em: https://www.gov.br/mdh/ptbr/navegue-por-temas/politicas-para-mulheres/ligue-180.
}

Revista de Direito Brasileira | Florianópolis, SC | v. 28 | n. 11 | p.131-163 | Jan./Abr. 2021 
por outras decisões no mesmo rumo, pondera um processo organizado que reorganiza os papeis e poderes dos juízes. Contudo, Araújo (2018, p. 130) observa o ativismo como processo que desregula a prática jurídica e defende a criação de mecanismos constrangedores, no campo da interpretação, às práticas ativistas para "equilibrar o saudável exercício da jurisdição constitucional". Outra corrente, de acordo com Cohn e Kremnitzer (2005), utiliza o termo "ativismo judicial" quando os resultados são contrários a seu entendimento do correto.

A crítica objetiva deste ativismo judicial, é a atividade criativa do juiz em proteger e criar direitos. Este segundo movimento seria, para Araújo (2018), ultrapassar as fronteiras, um processo que emerge reações e reduz o poder do legislativo. $\mathrm{O}$ autor entende a dualidade levantada por Koerner (2013) e Miarelli e Lima (2012) acerca da efetivação dos direitos, assim como da negligencia do poder legislativo em abranger pessoas desprotegias no texto constitucional, todavia, isto não é motivo para retirar o legislativo, a escrita de normativas que criam direitos - o que acontece quando juízes criam normas.

Araújo (2018) defende o respeito aos precedentes afim da segurança jurídica com mudanças incrementais na interpretação, de ordem a não interferir em outros poderes. $\mathrm{O}$ autor cita a ADI 4.277 e da ADPF 13227, julgadas pelo STF, que tratam da união homoafetiva, como exemplos a serem seguidos, tendo em vista que o Estado brasileiro já vinha reconhecendo em alguns procedimentos normativos, a união homoafetiva. A decisão reconheceu os direitos dos casais homoafetivos, em que a questão em tela era sobre plano de saúde. Para Araújo (2018), o STF não agiu de forma ativista, não criando legislação e apenas interpretando a legislação equiparando casais heteroafetivos a homoafetivos.

Para Cohn e Kremnitzer (2005), o ativismo judicial precisa ser analisado em três contextos argumentativos: 1) o judiciário como lócus de resolução de disputas legais; 2) o judiciário como operante na esfera pública em contexto de participante em rede com outros atores públicos e privados, governamentais ou não, que decide em dinâmica de interdependência com demais Poderes; 3) o papel das cortes nos arranjos constitucionais como algo que expande para além da proteção do processo dos valores centrais. Assim, as três visões constituem três modelos de ativismo judicial, respectivamente: 1) quando as cortes mudam as leis e decidem a partir de questões políticas e sociais; 2) quando o consenso social construído na rede constitucional é rompido em uma decisão das cortes; 3) quando há afastamento dos valores centrais constitucionais em uma decisão da corte.

Este ativismo judicial está afastado das interpretações a respeito das recentes decisões do Supremo Tribunal Federal acerca do reconhecimento de direitos para pessoas trans. Lins Júnior e Mesquita (2019) entendem que os contextos destes direitos não produzem novos direitos criados pelo STF, mas o respeito à direitos que não negados na aplicação do Direito, tendo em vista que o regime democrático não alude apenas o governo da vontade da maioria, mas, concomitantemente, respeito e preservação de valores e direitos fundamentais de minorias. Quando estes direitos são negados, é o judiciário quem tem de preservar as instituições democráticas e valores fundamentais, inclusive, reconhecendo a omissão de outro Poder, portanto, tem-se em vista "um sentido jurídico ao que está posto na ordem constitucional", sem criar um novo direito ${ }^{8}$ (LINS JÚNIOR; MESQUITA, 2019, p. 166).

Por outro lado, como ressaltado por Koerner (2013), Miarelli e Lima (2012) e Cohn e Kremnitzer (2005), Lins Júnior e Mesquita (2019, p. 171) enfatizam que juízes e tribunais podem estar mais próximos às representatividades de anseios e demandas sociais, quando comparados às instâncias políticas tradicionais, o que, em contextos de omissões dos Poderes ou por lacuna

\footnotetext{
${ }^{8}$ Isso não significa que juízes não excedam limites e criem novos direitos. De acordo com Lins Júnior e Mesquita (2019, p. 168): "no Brasil, apesar da importância dada à interpretação constitucional na produção das normas, criticase a ausência de mecanismos que objetivam conter possíveis excessos dos juízes, demonstrando uma inconsistência no próprio ideário da democracia contemporânea". Este seria um "(neo)constitucionalismo à brasileira".
} 
normativa, "empurram a história, quando ela emperra", assim como acabam por incitar que órgãos governamentais realizem as mudanças espontaneamente antes da decisão do litigio.

Ao contrário de Araújo (2018), Lins Júnior e Mesquita (2019) entendem a ocorrência de ativismo judicial na ADPF 132, no âmbito do reconhecimento da União Estável entre pessoas do mesmo sexo, por conta do processo argumentativo da negação de direitos à um grupo quando a maioria exerce, ao contrário da argumentação conservadora da criação de novos direitos. $\mathrm{O}$ ativismo se defronta com a "postura messiânica do Legislativo", em que militantes LGBTQ+ deveriam organizar, junto ao Congresso "correlação de forças favorável" para que este legisle "sobre pontos que já são constitucionalizados, porém não reconhecidos na prática". O que se observa, é a organização política frente aos mecanismos tradicionais de elaboração legislativa que homogeneízam e hegemonizam valores e normas, o que desafia os modelos argumentativos de consenso judiciário de Kmiec (2004), Tate e Vallinder (1995) e Cohn e Kremnitzer (2005).

No caso específico da ADI 4.275, Lins Júnior e Mesquita (2019), em que o que estava em jogo era a substituição de prenome e sexo civil de pessoas trans independentemente de cirurgia de transgenitalização, preceitos constitucionais da dignidade da pessoa humana, igualdade e liberdade, privacidade e vedação de discriminações odiosas, são os elementos que constroem a argumentação de que estes direitos, que são usufruídos pela maioria da população, são negados às pessoas trans. Assim, se percebe "o papel contramajoritário da Corte Suprema, resguardando direitos fundamentais e as próprias regras do jogo democrático", não configurando, igualmente, uma intromissão (Lins Júnior; Mesquita, 2019, p. 187), uma vez que os objetivos e os princípios fundamentais ao Estado Democrático de Direito, já previstos, são estendidos às pessoas trans, ao mesmo tempo em que, considerando o vazio constitucional e o contexto vulnerável envolvido, é justificável a posição contramajoritária do Judiciário.

No âmbito da América Latina, Wilson e Gianella-Malca (2019) destacam que processos de redemocratização associados à melhoria das condições de participação social, construíram bases de articulação de pessoas para articulação política e reivindicação de direitos. Estes direitos seriam reivindicados em duas categorias: 1) proteção e igualdade (que envolvem não discriminação, bemestar, propriedade e pensão, ou seja, direitos derivados de reconhecimento civil; 2) casamento igualitário. Os autores apontam, igualmente, que, em alguns casos, pessoas LGBTQ+ obtiveram mudanças legais no primeiro tipo direitos, relativos à proteção e igualdade, com criação de leis de combate à discriminação, tipificação penal e inscrição de programas públicos de reconhecimento civil. No caso do segundo tipo de direitos, o sucesso foi mediante interpretação de cortes superiores, não necessariamente, via mudança legislativa.

A via judicial, sobretudo no contexto do ativismo judicial, se tornou a válvula de escape de movimentos sociais de reivindicação de direitos às pessoas LGBTQ+, para forçar a discussão ao direito a ter direitos. Mesmo que isso represente, de acordo com Wilson e Gianella-Malca (2019), Kmiec (2004), Tate e Vallinder (1995) e Cohn e Kremnitzer (2005) uma pretensa ideia de que o Poder Judiciário consiga reescrever direitos econômicos, sociais e políticos, ou seja, prover mudanças sociais em sociedades que apresentam estruturas que negligenciem, deliberadamente, pelo Poder Legislativo, direitos à grupos considerados marginalizados. Diz Peres (2013, p. 301) que em circunstâncias específicas e articuladas, a arena jurídica alude a mover uma sensibilidade normativa às reivindicações de grupos minoritários, especialmente quando ocasiões onde o processo político majoritário é insuficiente em prover aspirações de minorias estigmatizadas.

Lee Epstein (2017) considera, inclusive, que as próprias cortes superiores se sentem constrangidas em deliberar por decisões que deveriam ser tomadas por outros poderes, já que sua função é interpretar e não criar leis, o que denota falta de legitimidade por não ser um Poder imbuído de escolha representativa da população, assim como os processos derivados da decisão afetariam os acordos políticos sobre a temática em tela. Já Charles Epp (1998) entende que certas decisões são necessárias, tal como o enfrentamento ao status quo, afim de construção de conscientização de direitos que sejam parte do desenvolvimento moral das pessoas, como algo que 
deve ser igualitário e não discriminatório. Neste último ponto, Epp (1998, p. 17) desenvolve a argumentação já advogada: que direitos não efetivados requerem "suporte à perseguição dos direitos". O que é ressaltado por Cenziper e Obergefell (2016) na questão de que a efetivação de direitos negados não veio por casas legislativas, mas por vias judiciárias, as quais, confrontando as primeiras, suscitaram no debate, o alto grau de violência sofrida e a necessidade de arcabouço protetivo.

A principal questão derivada neste processo, se volta a compreender que os direitos relativos às pessoas LGBTQ+ não são desenvolvidos em arenas políticas que contenham estruturas legais de oportunidades que se deem em condições igualitárias. Como apontam Cepeda Espinosa (2004), Uprimny (2007) e Wilson (2009), as mudanças políticas, sociais e culturais que culminaram em mudanças nas estruturais legais de reivindicação de direitos é processo recente na América Latina, colocando o acesso aos direitos como pauta igualmente recente na leitura dos textos constitucionais. A compreensão até então era de que estes grupos não detinham base para reivindicar direitos, uma vez que não eram moral, civil nem politicamente dignos aos direitos.

De acordo com Albarracín (2011), o papel de associações políticas na advocacy de litígios frente ao reconhecimento de direitos civis, também é elemento importante na compreensão de que as reivindicações se deram em contextos mobilizadores de elevar percebidas como "de grupos" a questões de negação geral de direitos que afetam a própria estrutura de direitos de toda a população. Isso é reforçado por Wilson e Gianella-Malca (2019), em que grupos políticos associados às pautas LGBTQ+ passaram a apoiar, social, política e juridicamente, ações individuais que pautassem litígios de caráter constitucional, objetivando articular mobilização social com discussão jurídica na negligência de direitos ou a sua não efetivação.

Uprimny (2007) ressalta que este movimento procura ampliar o caráter democrático reivindicatório, inclusive, das próprias pautas em si, redirecionando para a dimensão dos direitos humanos e sua fraca proteção. Em certa medida, podem até reconfigurar as discussões políticas para o debate sobre uma Agenda de Direitos que inclua o reforço à fiscalização do Estado em relação à efetivação de direitos, assim como à criação de novos direitos quando da inexistência de arcabouço normativo, desafiando as resistências políticas e administrativas de instituições burocráticas (CEPEDA ESPINOSA, 2004; WILSON, 2009; EPP, 1998; CENZIPER \& OBERGEFELL, 2016; MIARELLI \& LIMA, 2012). O Judiciário se torna, assim, de acordo com Keck (2009), a instância a qual grupos politicamente minoritários (considerados desagradáveis e rebaixados institucional pelas instituições legislativas, sendo, inclusive, afastados dos procedimentos deliberativos), recorrem para buscar guarida institucional e efetivação clara de direitos que lhes são negados.

Podemos seguir o entendimento de Ronald Dworkin (2002) de que a interpretação é elemento central nas decisões judiciais, sendo exercida em três fases: 1) pré-interpretativa, em que se identificam regras e padrões que pautam a prática objeto que se interpreta; 2) interpretativa, em que se ordena uma justificativa geral aos elementos críticos da prática que foi identificada; e 3) pós-interpretativa, onde tem-se a justificação, com o ajuste de argumentos substantivos referentes aos princípios que foram indicados na fase interpretativa. Essa justificativa delimita o intérprete como alguém que ajusta todos os aspectos de forma suficiente a ver-se como intérprete de fato, e não como alguém que criaria uma nova lei, ratifica Dworkin. Considera-se, além disso, o devido processo legal, a justiça e a equidade como as três virtudes políticas de um estado democrático que pondera os arquétipos de legitimação tanto do direito, quanto das instituições políticas. Dworkin acrescenta (2002) a integridade como um ideal político, onde governos devem tratar todos os cidadãos igualmente em respeito e consideração.

A integridade é uma concepção de dignidade humana que se relaciona à responsabilidade. Para Dworkin (2011, p. 200-205), cada pessoa deve levar sua própria vida à sério, pois a vida é uma realização e não oportunidade que pode ser descartada - esta interpretação orienta o que o autor denomina por Princípio do Autorrespeito, que não deve ser confundido como princípio moral, 
mas entendido como atitude, cuja concepção se relaciona com David Hume e Immanuel Kant a respeito do ser humano como um fim em si mesmo. Dworkin conjuga o autorrespeito com o Princípio da Autenticidade, em que o indivíduo é responsável por identificar o que é de fato importante em sua vida, conforme sua própria narrativa acerca de valores apropriados (DWORKIN, 2011, p. 203-204).

Bunchaft (2013, p. 289) entende que "a análise de conceitos interpretativos não pode ser descritiva, neutra e desengajada, pois a estrutura dos valores políticos não é física, mas normativa”, portanto, "justiça, democracia, dignidade humana não são autônomos nem conflitantes, devendo ser analisados de maneira integrada". A autora procura analisar, à luz da teoria de Dworkin, como aliar unidade de valor na dimensão igualdade e liberdade no tocante a direitos de transexuais, a partir de decisões judiciais proferias pelo Superior Tribunal de Justiça brasileiro. Para Peres (2013, p. 295-299), em algumas das decisões ${ }^{9}$ prevaleceu uma leitura moral da Constituição Federal que "que rompe com autocompreensões assimétricas de mundo", em que "princípios constitucionais da intimidade, da honra e da dignidade da pessoa humana foram analisados de forma interdependente entre si, de forma a se unirem em uma rede harmoniosa".

A partir da leitura de Dworkin, existiria uma incompatibilidade entre democracia e direitos fundamentais, uma vez que "a despeito de uma multiplicidade de concepções de vida digna, os cidadãos compartilham uma concepção de justiça decorrente do fato de que todos os cidadãos devem ser tratados com igual respeito". Considerando este contexto, determinadas decisões de caráter político majoritário não necessariamente conseguem alcançar concepções éticas individuais, consequentemente, deve-se conceber a salvaguardar de um "um complexo de direitos fundamentais frente ao poder de decisão das maiorias, com fundamento no princípio da autonomia moral" (PERES, 2013, p. 298-299).

\section{UM PARALELO QUANTO AO DIREITO DE PESSOAS TRANSEXUAIS E TRANSGENEROS NA SUPREMA CORTE NORTE AMERICANA}

Nos Estados Unidos, a discussão acerca dos direitos de pessoas transgêneros em debate na Suprema Corte data de um conjunto de decisões relativas à três casos finalizados em 15 de junho de 2020. Em cada um dos três casos, um empregado alega a demissão, pelo empregador, decorrente de discriminação por conta do empregado ser homossexual ou transgênero. A controvérsia em disputa era: um empregador que demita uma pessoa por ser homossexual ou transgênero, violaria a Lei dos Direitos Civil, especificamente, seu Título VII, "Oportunidades Iguais de Contratação"?

Consideremos o parágrafo $2^{\circ}$ da seção 703 (“Oportunidades Iguais de Contratação"), do "Civil Rights Act of 1964", em particular, a alínea "b” em sua integralidade e a segunda parte da alínea "e":

SEC. 703. (a) It shall be an unlawful employment practice for an employer:

(1) to fail or refuse to hire or to discharge any individual, or otherwise to discriminate against any individual with respect to his compensation, terms, conditions, or privileges of employment, because of such individual's race, color, religion, sex, or national origin;

(...)

(b) It shall be an unlawful employment practice for an employment agency to fail or refuse to refer for employment, or otherwise to discriminate against, any individual because of his race, color, religion, sex, or national origin, or to classify or refer for employment any individual on the basis of his race, color, religion, sex, or national origin.

(e) Notwithstanding any other provision of this title,

\footnotetext{
${ }^{9}$ Ver em Sentença Estrangeira n. 001058. Voto do relator, Ministro Barros Monteiro. Brasília, DF, Diário da Justiça,
} de 4 de dezembro de 2006.

Revista de Direito Brasileira | Florianópolis, SC | v. 28 | n. 11 | p.131-163 | Jan./Abr. 2021 


\section{(..)}

(2) it shall not be an unlawful employment practice for a school, college, university, or other educational institution or institution of learning to hire and employ employees of a particular religion if such school, college, university, or other educational institution or institution of learning is, in whole or in substantial part, owned, supported, controlled, or managed by a particular religion or by a particular religious corporation, association, or society, or if the curriculum of such school, college, university, or other educational institution or institution of learning is directed toward the propagation of a particular religion (USC, 1964, p. 255-256)

A alínea "a" entende como prática ilegal de contratação deixar de contratar alguém (ou criar contratos diferentes) com base na discriminação de raça, cor, religião, sexo ou nacionalidade. O item "2" da alínea "e" abre salvaguarda às instituições ou organizações educacionais que podem se recusar a contratar, considerando que algumas das cinco dimensões - raça, cor, religião, sexo ou nacionalidade - vá contra às suas concepções definidoras. Duas questões são levantadas neste momento; 1) como categorizar a homossexualidade e a transgeneridade (as duas controvérsias na disputa) nas cinco dimensões; 2) observar se o privilégio concedido às instituições/organizações educacionais se estende a quaisquer instituições/organizações. Não obstante, outra questão transversal indagava se as vítimas de discriminação contra homossexuais e transexuais estavam amparadas pela Lei de Direitos Civis.

Os três litígios, portanto, versavam sobre se o fato de uma pessoa ser homossexual ou transexual se encaixava nas categorias descritas como objeto de discriminação, a saber: raça, cor, religião, sexo ou nacionalidade. Os três casos são considerados marcos por a Suprema Corte dos Estados Unidos entender que o Título VII da Lei dos Direitos Civis de 1964 protege os funcionários contra a discriminação por causa de sua orientação sexual ou identidade de gênero. A corte entendeu que os empregadores que discriminam funcionários homossexuais ou trans aceitam certa conduta em funcionários de um sexo, mas não em funcionários do outro sexo, o que constrói elementos discriminatórios.

No caso Bostock vs. Clayton County, Gerald Bostock, um empregado do Condado de County, no Estado da Geórgia, foi despedido depois de manifestar interesse em uma liga gay de softball no trabalho, em razão de "conduta inapropriada aos funcionários do Condado". O estado da Geórgia é um dos que não tem leis sobre discriminação aos LGBTQ+. Bostock apelou judicialmente e a decisão no tribunal local manteve a demissão, em seguida, apelou em segunda instância, cujo tribunal manteve a decisão, alegando a iexistência da discriminação. Assim, o caso vai parou na Suprema Corte por apelação de Bostock.

No caso Altitude Express, Inc. v. Zarda, Donald Zarda, era um instrutor de paraquedismo da empresa Altitude Express, que confidenciou o fato de ser homossexual à uma cliente, para deixála mais confortável estando ligada a ele durante um salto de paraquedas. A cliente e seu namorado posteriormente noticiaram suas oposições à empresa, levando à demissão do apelante sob a alegação de má conduta. Zarda entrou com uma ação em 2014 com base em discriminação no emprego e, conquanto o apelante tenha vido à óbito em um acidente de paraquedismo no mesmo ano, sua família continuou o processo judicial. Na primeira apelação, o Tribunal Distrital decidiu a favor da Altitude, mas, em segunda instância, a decisão foi revogada, considerando que o Título VII da Lei dos Direitos Civis protege os funcionários da discriminação com base na orientação sexual. Com a decisão, da Altitude Express, Inc. apela à Suprema Corte.

Já no caso RG \& GR Harris Funeral Homes Inc. v. Equal Employment Opportunity Commission, a apelante Aimee Stephens era uma funcionária de uma funerária que se apresentava como homem até 2013, quando, neste mesmo ano escreveu ao seu empregador, o grupo Harris Funeral Homes, para que tivessem ciência de sua decisão de realizar uma cirurgia de redesignação de gênero. Inclusive, a carta indicava que, após seu retorno, Stephens planejava retornar vestida 
com roupas femininas. Stephens foi demitida após o envio da carta. Na primeira instância, o Tribunal Distrital decidiu pelas casas funerárias, destacando que o Título VII não cobria pessoas trans e que, como a funerária estava amparada sob a Lei de Restauração da Liberdade Religiosa, por ser uma organização religiosa, a empresa tinha o direito de demitir Stephens por "não conformidade". Em segunda instância, o tribunal reverteu a decisão, entendendo que o Título VII da lei dos Direitos Civis incluía proteção para pessoas trans. Aimee Stephens veio a óbito pouco tempo depois, todavia, o processo continuou em curso com RG \& GR Harris Funeral Homes Inc. apelando à Suprema Corte.

Chama a atenção que nos três casos, as cortes distritais de primeira instância deram provimento à interpretação de que o Título VII da lei dos Direitos Civis não incluía proteção para pessoas trans e que as cortes dos tribunais de apelação reverteram todas as decisões, entendendo que Título VII da lei dos Direitos Civis incluía. Ao mesmo tempo, em 2, dos 3 casos, familiares deram continuidade ao processo, com a Suprema Corte entendendo a temática como questionadora da Constituição. Os três processos foram julgados pela Suprema Corte dos Estados Unidos em conjunto, com seis ministros, entendendo que o Título VII da Lei dos Direitos Civis protege os funcionários da discriminação com base na orientação sexual ou identidade de gênero e três ministros divergindo sob a alegação de que a Suprema Corte estava assumindo papel legislador, extraindo competência não prevista constitucionalmente e usurpando posição de outro Poder, no caso, a Câmara dos Deputados e o Senado norte-americano.

Para a Suprema Corte, o sexo exerce papel definitivo no motivo que orienta a decisão de demissão posto em tela nos três casos, não obstante o fato de que três empregados demitidos possuíam excelentes credenciais e histórico de alto potencial no trabalho, o que não foi suficiente a barrar suas demissões. A Corte ratifica a ideia de que a Corte deve acompanhar os tempos e reinterpretar normas à luz do presente, considerando o lapso temporal em que normas são escritas e caducam com o tempo, portanto, a questão debatida convergia a decidir se se "continuaria a negar às pessoas o direito a continuar em base interpretativa do sentido original da lei em sua constituição original para definir seus direitos e obrigações" (SCUS, 2020, p. 8).

Para isso, seria necessário ampliar a concepção pública de proteção de direitos civis a ser abrangida pela Lei. A Corte entendeu que era preciso partir do único termo possivelmente relacionado na Lei, no caso, "sexo", originalmente concebido em viés biológico, mas que, mesmo nesta época, "capturaria mais que simples anatomia e alcançaria, ao menos, normas concernentes à identidade de gênero e orientação sexual" (SCUS, 2020, p. 9). Todavia, a Corte inverteu: afastou a concepção do sexo para interpretar a lei dos Direitos Civis para focar no que a Lei proibia em si, ou seja, a demissão em razão de ou por conta de.

A partir de precedentes da própria Suprema Corte, o entendimento dos ministros recaiu na ideia de que já existia jurisprudência a respeito da definição dos termos em razão de ou por conta de, em termos de causalidade, quando "é estabelecido qualquer resultado que não teria acontecido diretamente pela causa perpetrada" (SCUS, 2020, p. 9), sobretudo, quando outra causa não pode ser evocada. Assim, a Corte entendeu pela evocação do sexo na relação de causalidade como elemento inicial. Inclusive, neste ponto, a corte indicou a fragilidade legislativa do Congresso em definir regras específicas para interpretar o que se entendia como discriminatório à época: uma diferença de tratamento que trazia de uns em relação a outros.

A Corte também entendeu que a base discriminatória de 1964 era sobre indivíduos e não grupos, o que, não pode ser a interpretação a ser dada em 2020, ano do julgamento. A defesa contra a discriminação não é sobre indivíduos, mas sobre as representações sociais e papeis que indivíduos incorporam e servem como base de tomada de decisão. Um homem não seria demitido por ser homem, mas seria demitido por incorporar um papel não relacionado à representação social de um homem (em relacionamento homossexual, a representação heterossexista associa o papel masculino à relação heterossexual e não homo). Portanto, homossexualidade e transgeneridade estão relacionados à papeis e representações sociais baseadas no "sexo", assim, a Suprema Corte 
alcançou a discriminação, por conta de que "a discriminação, nestes termos, requer que um empregador intencionalmente trate individualmente seus empregados diferentemente por conta de seu sexo" (SCUS, 2020, p. 14).

O sexo do indivíduo permite o início da argumentação, mas no caso de homossexuais e trangêneros, existe uma segunda implicação que o Título VII da lei dos Direitos Civis não tem orientação clara, mas que a discriminação do homossexual ou do transgênero envolve discriminação com base no sexo, já que "é impossível discriminar uma pessoa por ser homossexual ou transgênero sem discriminar esse indivíduo com base no sexo" (SCUS, 2020, p. 13). A corte dá como exemplo duas pessoas, um homem e uma mulher, em que se a mulher apresenta um homem como um cônjuge não há aplicação de discriminação quando da demissão, por outro lado, quando um homem apresenta outro homem como seu cônjuge e, em consequência, é demitido, há alusão do sexo e gênero como interdependentes na tomada de decisão para a demissão. O mesmo se daria nem outro exemplo, dois homens, em que o primeiro se veste, performa e se identifica pelas características masculinas, não incorrendo em discriminação quando de uma possível demissão, por outro lado, o segundo, se passa a se vestir, performar e se identificar como mulher, a demissão com base nestes papeis pode incorrer em discriminação (o segundo exemplo pode se referir à transgêneros, independente de realização de cirurgia de redesignação sexual).

A Corte entende que o processo de demissão é justificado a partir de evocações de motivos. Demitir alguém por sua homossexualidade ou transgeneridade evoca compreender as dimensões sexuais e de identidade a partir do gênero e sexo em suas múltiplas relações psicossociais, morfológicas, normativas e judiciais. Estas dimensões incidem expectativas e normas de gênero, ou seja, perspectivas pautadas em uma ordem social, jurídica e política que demanda certos comportamentos e identidades percebidos como "normas". Quando as normas não condizem (heterossexualidade versus homossexualidade e homem/mulher com padrões e corpos delimitados versus transgeneridade), se evoca o motivo da demissão, portanto, a justificativa incide sobre gênero e sexo.

O grupo que discordou da decisão da maioria entendeu que não há discriminação do homossexual ou do transgênero com base no sexo, ou seja, a demissão é por ser homossexual ou transgênero, não por conta do sexo em si, logo, não há discriminação porque não há correlação causal nem discriminação intencional. Contudo, a maioria da corte inverteu este argumento, situando que não há como saber se uma pessoa é homossexual ou transgênero sem apelar à compreensão de sexo, porque se um homem se relaciona amorosamente com uma mulher, não haveria discriminação quando da demissão, mas se este homem se envolvesse com outro homem, existiria a discriminação. Assim, a questão é solucionada: há relação entre sexo e gênero na percepção da homossexualidade e transgereridade.

Outro argumento do grupo que discordou da decisão da maioria é que os termos "homossexualidade" e "transgeneridade" não existem na Lei, assim como são distintos de "sexo". E que quem deveria incluir era o Congresso norte-americano, já que a Suprema Corte não seria imbuída de criação de leis (SCUS, 2020, p. 13) ${ }^{10}$. A maioria da corte também inverteu este argumento, indicando que quando o Congresso não se debruça na temática (mesmo quando estimulado a tal), a controvérsia engendra reação da Suprema Corte, a qual deve responder aplicando a regra mais ampliada - e isto não seria novidade no histórico da própria Corte, ao mesmo tempo em que aplicar a regra mais ampliada não é criar leis, mas efetivá-las.

Por fim, podemos compreender o movimento realizado pela Suprema Corte na seguinte forma:

A partir de uma controvérsia em que se decidiria se homossexuais e transgêneros estariam incluídos na possibilidade de sofrerem discriminação de raça, cor, religião, sexo ou nacionalidade, a Suprema Corte evocou interpretações derivadas da dimensão "sexo" para incluir interpretações

${ }^{10}$ Notadamente, o grupo minoritário é contra qualquer possibilidade de ativismo judicial.

Revista de Direito Brasileira | Florianópolis, SC | v. 28 | n. 11 | p.131-163 | Jan./Abr. 2021 
psicossociais, políticas e jurídicas para delimitar que "sexo" comporta estas dimensões e não apenas a base biológica.

Com a referida interpretação, a Corte associou sexo à gênero como imbrincados no mecanismo discriminatório, alegando que não há como interpretar a homossexualidade e transgeneridade (os objetos da controvérsia) sem sexo e gênero. Este movimento permitiu associar a identidade de gênero (pela transgeneridade) e a orientação sexual (pela homossexualidade) ao "sexo", como elemento não discriminatório, indicado no texto do parágrafo $2^{\circ}$ da seção 703 da Lei dos Direitos Civis.

Com a associação, a justificativa encontra amparo da interpretação mais ampliada das regras, dispositivo já utilizado pela Corte para solucionar litígios da mesma espécie reivindicatória de direitos que não estejam explicitamente descritos na Lei. É ressaltado que indivíduos não podem ficar desamparados em interpretações minimalistas por conta de uma incumbência constitucional não permitida à Suprema Corte, no caso, a criação de leis. Pelo contrário, a Corte não estaria legislando, nem inventando novos sujeitos ou direitos, mas garantindo a efetivação de direitos que estejam em dubiedade de sua aplicação.

\section{AS DECISÕES NO SUPREMO TRIBUNAL FEDERAL}

\subsection{Ação direta de Inconstitucionalidade 4.275 Distrito Federal de 2009 e Recurso Extraordinário 670.422 de 2012 do Rio Grande do Sul}

A Ação Direta de Inconstitucionalidade 4.275 do Distrito Federal de $2009^{11}$ e julgado em 2018, tratava sobre o caso concreto de uma pessoa transexual alterar seu prenome e sexo no registro civil, considerando o reconhecimento da personalidade jurídica e o direito à liberdade pessoal, à honra e à dignidade, independente de exigibilidade de cirurgia de transgenitalização ou da realização de tratamentos hormonais ou patologizantes. Foi julgada em conjunto com o Recurso Extraordinário 670.422 do Rio Grande do Sul. As questões colocadas apontavam em três questões: 1) o reconhecimento do direito da pessoa transexual de modificar seu registro civil; 2) sendo a mudança derivada ou não de decisão judicial, assim como sua obrigatoriedade ou não; 3) se processos médicos de intervenção cirúrgica são requisitos ou não ao processo de alteração do registro civil.

O Recurso Extraordinário 670.422 de 2012 do Rio Grande do Sul ${ }^{12}$ versava sobre decisão da Oitava Câmara Cível do Tribunal de Justiça daquele estado. Foi julgado em conjunto com a Ação Direta de Inconstitucionalidade 4.275 do Distrito Federal, já comentada, logo, nos ateremos às considerações apenas do relator, Dias Toffoli. A referida ação pleiteava alteração de registro civil, contendo mudanças no nascimento, nome e da anotação referente ao gênero, de feminino para masculino. O pleito indicava a "condição de transexual"13 e os desconfortos vivenciados pelo autor da ação. Como provas do processo, incluem perícia judicial em que se apontam "periciada(o) tem aparência e postura nitidamente masculinas, sendo impossível identificá-lo como mulher", ao passo em que possui "personalidade e identidade de gênero masculinas que destoam de seu gênero biológico". A ação na primeira instancia julgou parcialmente procedente o pedido, tendo sido determinada a alteração do prenome, todavia, impedida a alteração do sexo biológico, pelo juízo entender como condicional a realização de procedimento cirúrgico de redesignação sexual para "adequação do sexo biológico de nascimento ao sexo psicossocial", o que não teria ocorrido (RE $670.422,2012$, p. 7-10).

\footnotetext{
${ }^{11}$ ADI n .4275 de 2009. Disponível em: <https://jurisprudencia.stf.jus.br/pages/search/sjur399205/false>. Acesso em 15 de outubro de 2020.

${ }^{12} \mathrm{RE} \mathrm{n} \mathrm{n}^{\circ}$. 670422. Disponível em: <https://jurisprudencia.stf.jus.br/pages/search/sjur420306/false>. Acesso em 15 de outubro de 2020.

${ }^{13}$ A pessoa foi diagnosticada pela CID-10 com "transexualismo".
}

Revista de Direito Brasileira | Florianópolis, SC | v. 28 | n. 11 | p.131-163 | Jan./Abr. 2021 
Assim posto, a controvérsia julgada era a necessidade ou não da cirurgia de redesignação sexual para que uma pessoa transexual possa alterar, além do nome, o sexo biológico. Esta controvérsia compreendeu, inicialmente a transgenitalização desde a identificação pessoal, ao acompanhamento médico e psicológico, o procedimento cirúrgico e posterior acompanhamento. Em consequência, outra controvérsia foi apresentada: a sugestão do Tribunal na primeira instância, em caso de não necessidade da cirurgia, de constar no registro civil a condição de transexual ${ }^{14}$. $\mathrm{O}$ revisor da ação indicou que não era necessário que se alterasse o registro civil, tendo em vista que, no âmbito da vida civil, os documentos necessários não possuem identificação do gênero do seu portador $^{15}$ (RE 670.422, 2012, p. 10).

$\mathrm{O}$ acordão de $1^{\circ}$ de março de 2018 da ADI 4.275 é permeado de questões relativas às concepções de gênero, sexo, transexualidade, transgeneridade, travestilidade, homossexualidade dentre outras noções. O texto contém trechos do julgamento e deixa claro como ministros alteraram opiniões a partir da leitura de votos antecipados de outros colegas e que tinham votos substanciados conceitual e juridicamente a partir de obras temáticas à questão dos direitos dos transexuais e transgêneros. Os ministros, inclusive, modificaram o termo transexual para transgênero para fundamentar a perspectiva do voto afastando elementos médicos e judiciais no entendimento da decisão ${ }^{16}$.

O plenário do Supremo Tribunal Federal considerou que o direito à igualdade sem discriminações abrange a identidade ou expressão de gênero, entendida como "manifestação da própria personalidade da pessoa humana e, como tal, cabe ao Estado apenas o papel de reconhecêla, nunca de constituí-la” (ADI 4.275, 2009, p. 2). A premissa acerca da pessoa transgênero referente à sua identidade de gênero é que a mesma tem o direito fundamental subjetivo à alteração do prenome e da classificação de gênero no registro civil pela via administrativa ou judicial independentemente de procedimento cirúrgico e laudos de terceiros, pela compreensão de que se envolve o direito fundamental ao livre desenvolvimento da personalidade. A ação foi considerada procedente para dar interpretação conforme a Constituição Federal Brasileira e o Pacto de São José da Costa Rica ao art. 58 da Lei 6.015/73.

A controvérsia submetida ao STF consistiu em definir se é possível a modificação de prenome e gênero de transexual no registro civil, independentemente da realização de cirurgia de transgenitalização. $\mathrm{O}$ voto do ministro relator (que serve como base de apoio ou contestação), Marco Aurélio Mello, diferencia transexualidade, homossexualidade e travestilidade, citando estudos científicos de autores reconhecidos na temática que problematizam aspectos legais, sociais, econômicos, saúde e violência. Fundamental reconhecer que o ministro pondera sobre normas sociais pautadas em padrões sociais que marginalizam e negam direitos fundamentais, assim como impedem a dignidade da pessoa humana. $\mathrm{O}$ relator fundamentou o voto a partir de elementos

\footnotetext{
${ }^{14} \mathrm{O}$ argumento do revisor da ação na primeira instância é curioso, por apontar, sem comprovar, que "por mais que a ciência tenha avançado, e com todos os recursos da cirurgia, transexuais ainda não são capazes de adquirir todas as características do sexo oposto ao que nasceram" (RE 670.422, 2012, p. 10). Ao mesmo tempo, não está claro quais características são essas a que o revisor se refere, se são psicológicas, físicas, mentais etc., Não obstante, podemos perceber uma caricaturização.

${ }^{15}$ Evidentemente, trata-se de um direito incompleto, de segunda classe, reduzindo o transexual à pessoa moral e jurídica imperfeita (quando não incompleta), não tendo direito ao direito e à consideração de sujeito de justiça. Paralelamente, a decisão judicial destaca não apenas a percepção, mas a chancela do Estado e sua compreensão sobre sujeitos incompletos. Não obstante, o Estado, além de rebaixar indivíduos, esconde a decisão pelo fato deste direito não ser percebido como exercido na esfera pública. Ver esta discussão a respeito dos direitos incompletos em Benhabib (2011).

${ }^{16}$ Há, especificamente, um momento em que o ministro Roberto Barroso muda seu voto, antes pensado em pessoas transexuais, e altera o termo de seu voto para "pessoas transgêneros", tendo em vista as sustentações orais das partes e amicus curiae. A corte também segue este raciocínio, apontando no acórdão, a seguinte tese: reconhecer aos transgêneros que assim o desejarem, independentemente da cirurgia de transgenitalização, ou da realização de tratamentos hormonais ou patologizantes, o direito à substituição de prenome e sexo diretamente no registro civil (ADI $4.275,2009$, p. 2-3)
}

Revista de Direito Brasileira | Florianópolis, SC | v. 28 | n. 11 | p.131-163 | Jan./Abr. 2021 
psicossociais que circundam a complexidade da escolha de pessoas transgêneros realizarem ou não os procedimentos necessários à redesignação sexual.

Contudo, há de ser ressaltado, que o Ministro Marco Aurélio indicou alguns requisitos para a mudança de registro civil em sua decisão, dentre elas, diagnóstico médico de transexualismo, presentes os critérios do artigo $3^{\circ}$ da Resolução n ${ }^{\circ} 1.955 / 2010$, do Conselho Federal de Medicina. Considerando que, de acordo com a $10^{a}$ Classificação Estatística Internacional de Doenças e Problemas Relacionados com a Saúde (conhecida como CID-10), de 1990, o "transexualismo" é considerado como "Transtorno da identidade sexual", ou seja, uma doença mental, é notório que o relator tenha se pautado em base médica para direcionar seu voto. A ministra Rosa Weber critica esta posição, ao afirmar que "a transexualidade ou neurodiscordância de gênero é comumente tratada como condição médica, e não moral" (ADI 4.275, 2009, p. 60), portanto, necessita de uma abordagem social que seja fundamentada no direito à autodeterminação da pessoa. $\mathrm{O}$ ministro Ricardo Lewandowski também tece críticas a este posicionamento de requisitos mínimos para mudança de nome, asseverando que "cabe ao julgador, à luz do caso concreto e vedada qualquer forma de abordagem patologizante da questão, verificar se estão preenchidos os requisitos para a mudança" (ADI 4.275, 2009, p. 119).

$\mathrm{O}$ voto do Ministro Alexandre de Moraes segue raciocínio semelhante, distinguindo "sexo" e "gênero", colocando a identidade de gênero com prevalência de elementos psíquicos sobre físicos ${ }^{17}$, em que a irreversibilidade da identificação psicológica desobriga a razoabilidade de se exigir do transexual a submissão aos riscos, e custos, de um procedimento cirúrgico ${ }^{18}$. A questão cirúrgica relativa ao corpo é levantada muito mais à frente por um outro ministro, Luiz Fux, de modo mais incisivo, ao entender uma errônea associação monolítica de reconhecimento de gênero com aparência física, o que seria compreensão limitante, pois "aparência não pode ser critério para concessão de direitos a transexuais" (ADI 4. 275, 2018, p. 107). Praticamente todos os ministros citam alguma concepção de gênero, todas muito próximas, contudo, é a ministra Carmen Lúcia quem assegura, enfaticamente, que "o gênero, diferentemente da morfologia sexual, é, antes de tudo, um elemento de identificação cultural” (ADI 4. 275, 2018, p. 150).

Luiz Fux pondera que o Processo Transexualizador não pode ter na orientação jurisprudencial a cirurgia de redesignação sexual como a etapa final para o sujeito a alterar seu registro civil, uma vez que isto é afronta ao direito do transexual realizar ou não o processo cirúrgico. E esta orientação jurisprudencial deve acompanhar os avanços civilizatórios de garantias de direitos ${ }^{19}$. Há de ser ressaltado que o voto do Ministro Roberto Barroso aponta o julgamento da referida ADI como "avanço do processo civilizatório [que] consiste na superação dos preconceitos" (ADI 4.275, 2009, p. 50). Tanto Barroso, quanto Fachin e Weber fazem menção ao princípio n 3 dos "Princípios de Yogyakarta sobre a Aplicação da Legislação Internacional de Direitos Humanos em relação à Orientação Sexual e Identidade de Gênero", conhecidos como "Princípios de Yogyakarta". Assim, avanços politicamente reconhecidos pelos estados em acordos internacionais devem ser considerados nas decisões constitucionais.

\footnotetext{
${ }^{17}$ A ministra Carmen Lúcia subscreve, considerando que "a identidade de gênero não pode espelhar o único critério da anatomia desconsiderando a vida psíquica do indivíduo" (ADI 4. 275, 2018, p. 169)

18 Alexandre de Moraes cita a 1BvR 3295/07, da Alemanha, em que o Tribunal Constitucional Federal (Bundesverfassungsgericht) declarou inconstitucional a exigência de prévia submissão a cirurgia de mudança de sexo. Também decidem neste aspecto, a Grã-Bretanha, onde o Gender Recognition Act, de 2004, delimita a inexigibilidade. Na Espanha, com a Lei n. 3, de 15/3/2007. Em Portugal, com a Lei n. 7, de 15/3/2011. E na Argentina, destacando a Lei n. 26.743, de 23/5/2012 (ADI 4.725, 2018, p. 4-6).

${ }^{19}$ Considero importante destacar o Decreto 8.727/2016, que dispôs sobre o uso do nome social e o reconhecimento da identidade de gênero de pessoas "trans" no âmbito da administração pública federal direta, autárquica e fundacional. Nesse decreto, foram estabelecidos os conceitos, no seu art. $1^{\circ}$, I e II, de nome social e de identidade de gênero, quais sejam: I - nome social - designação pela qual a pessoa travesti ou transexual se identifica e é socialmente reconhecida; e II - identidade de gênero - dimensão da identidade de uma pessoa que diz respeito à forma como se relaciona com as representações de masculinidade e feminilidade e como isso se traduz em sua prática social, sem guardar relação necessária com o sexo atribuído no nascimento.
}

Revista de Direito Brasileira | Florianópolis, SC | v. 28 | n. 11 | p.131-163 | Jan./Abr. 2021 
Ponderamos como importante o tratamento dado pelo Ministro Luiz Fux, ao considerar o uso do termo "transexual" em qualquer campo das certidões públicas como discriminatória e, portanto, inconstitucional, por violação à dignidade da pessoa humana ${ }^{20}$. Também entende o reconhecimento dos direitos à identidade de gênero como "realização pessoal do indivíduo e da busca da felicidade" (ADI 4.275, 2009, p. 91). Neste ponto, o ministro argumenta acerca dos direitos subsequentes ao registro civil referentes à "aposentadoria, o serviço militar obrigatório, a legislação trabalhista, o encarceramento prisional, o direito à hora extra feminina e licença maternidade por adoção" (ADI 4.275, 2009, p. 99).

A questão acima dos direitos subsequentes, traz luz à noção do reconhecimento civil de pessoas transgêneros como porta ao acesso à demais direitos vinculados que, por certo, até então negados, por conta do conflito do registro civil. O ministro Celso de Mello afirma em seu voto que a referida ADI é divisor de águas por ser parte de "decisões que fazem cessar o estado de invisibilidade imposto à coletividade dos transgêneros [...]possuem a virtude de congregar aqueles que reverenciam os valores da igualdade, da tolerância e da liberdade" (ADI 4.275, 2009, p. 123). Não obstante, se permite refundar valores contrários à discriminação e mais propícios à igualdade, afins de "em ordem a viabilizar, como política de Estado, a instauração e a consolidação de uma ordem jurídica genuinamente inclusiva" (ADI 4.275, 2009, p. 123).

Já o voto do Ministro Edson Fachin, que foi o voto divergente do relator e que foi acompanhado pela maioria dos ministros do STF, lembra que o Brasil é signatário de uma série de tratados internacionais, não estando incólume às questões de direitos fundamentais que sejam feridos no tratamento diferenciado entre cidadãos, portanto, "não se pode descurar das mais variadas obrigações a que o Brasil se vinculou na esfera internacional no que se refere à proteção dos direitos humanos" (ADI, 4.275, 2018, p. 32). Fachin ainda levanta uma afirmação básica: não é a pessoa quem deve provar o que é, ao mesmo tempo em que não é o Estado quem define ou condiciona a expressão da identidade. $\mathrm{O}$ direito à igualdade de gênero se refere à manifestação de sua identidade de gênero e diz apenas a seu respeito.

O Ministro concebe identidade de gênero a partir dos Princípios de Yogyakarta e da Corte Interamericana de Direitos Humanos ${ }^{21}$, elencando conceitos de identidade de gênero, complementares e afastando a patologia associada à pessoa trans. O voto do ministro decide procedente reconhecer aos trangêneros, que assim o desejarem, independentemente da cirurgia de transgenitalização, ou da realização de tratamentos hormonais ou patologizantes, o direito à substituição de prenome e sexo diretamente no registro civil. Por fim, foi Fachin quem levantou a mudança do termo transexual para transgênero no entendimento da corte afim de afastar elementos

\footnotetext{
20 O ministro também considera que viola expressamente mais quatro princípios: o da igualdade, por ato discriminatório flagrante e o da intimidade, por expor uma condição psíquica do sujeito. A terceira violação é decorrente do entendimento da necessidade de cirurgia de redesignação sexual, pois aqui seria violado o princípio da liberdade individual, assim como um quatro princípio, o da saúde, por colocar em risco a saúde decorrente de exigência cirúrgica.

${ }^{21}$ O primeiro: "como estando referida à experiência interna, individual e profundamente sentida que cada pessoa tem em relação ao gênero, que pode, ou não, corresponder ao sexo atribuído no nascimento, incluindo-se aí o sentimento pessoal do corpo (que pode envolver, por livre escolha, modificação da aparência ou função corporal por meios médicos, cirúrgicos ou outros) e outras expressões de gênero, inclusive o modo de vestir-se, o modo de falar e maneirismos".

O segundo: "também se encontra ligada ao conceito de liberdade e da possibilidade de todo ser humano autodeterminar-se e escolher livremente suas opções e circunstâncias que dão sentido à sua existência, conforme às suas próprias convicções, assim como ao direito à proteção de sua vida privada. [...] a identidade de gênero foi definida nesta opinião como a vivência interna e individual do gênero tal como cada pessoa o sente, o qual pode ou não corresponder com o sexo assinalado no momento do nascimento [...] longe de constituir-se em componentes objetivos e imutáveis do estado civil que individualiza uma pessoa, por ser um fato da natureza física ou biológica, terminam sendo traços que dependem da apreciação subjetiva de quem o detenha ou residam em construção de identidade de gênero auto-percebida relacionada com o livre desenvolvimento da personalidade, a autodeterminação sexual e o direito à vida privada".
}

Revista de Direito Brasileira | Florianópolis, SC | v. 28 | n. 11 | p.131-163 | Jan./Abr. 2021 
médicos e judiciais no entendimento da tese a ser seguida. Destaca-se, inclusive, a não necessidade de decisão judicial para a alteração do registro ${ }^{22}$. E este voto é o aceito pela corte para compor a base do acordão.

\subsection{Ação direta de Inconstitucionalidade por omissão 26 Distrito Federal de 2013}

A Ação Direta de Ação Direta de Inconstitucionalidade por Omissão 26 do Distrito Federal de $2013^{23}$ foi julgada em 2019 em conjunto com o Mandado de Injunção 4733 e versava sobre considerar condutas discriminatórias à homossexuais e transexuais como equiparadas ao crime de racismo previsto na lei $n^{\circ} 7.716 / 89$, considerando, inclusive, a inércia do estado em relação à edição de legislação concernente à punição dos atos lesivos tendo em vista a orientação sexual ou da identidade de gênero da vítima. Estas discriminações configuram expressões de racismo em sua dimensão social, até que sobrevenha lei do Congresso Nacional que delimite a matéria $^{24}$.

A Suprema Corte considerou aceitável a ADIO pela constada inércia do Congresso Nacional em legislar sobre a matéria e declarando a existência de omissão normativa inconstitucional $^{25}$, assim como proferiu que as práticas homotransfóbicas qualificam-se como espécies do gênero racismo por tais comportamentos ajustarem-se ao conceito de atos de discriminação e de ofensa a direitos e liberdades fundamentais. Paralelamente, estas práticas se conformam como qualificadores em crimes de homicídio (ADIO 26, 2013, p. 10). É ministro Roberto Barroso quem define, taxativamente, homofobia e transfobia como "violência física ou psicológica contra uma pessoa, respectivamente em razão de sua orientação sexual ou de sua identidade de gênero, manifestando-se em agressões, ofensas e atos discriminatórios" (ADIO 26, 2013, p. 281)

A premissa básica do voto do relator, ministro Celso de Mello, é o de que "ninguém pode ser privado de direitos nem sofrer quaisquer restrições de ordem jurídica por motivo de sua orientação sexual ou em razão de sua identidade de gênero (ADIO 26, 2013, p. 5), tendo em vista que as pessoas que se entendem por LGBTI $+{ }^{26}$ têm o direito à autodeterminação em matéria afetiva e amorosa, à igualdade de tratamento e busca de felicidade, o que corrobora a completude de direitos e não a sua privação. Tal como na ADI 4.275, a questão da garantia de direitos a grupos marginalizados é considerada a medida entre civilização e barbárie que envolve o processo civilizatório.

É evidente no texto do relator a construção social das relações de poder entrelaçadas na dimensão de gênero e sexualidade, compreendendo similaridades pela lógica do racismo, onde um grupo de orienta por elementos que caracterizam marcadores sociais negativos sobre outro grupo, subjugando-o, hierarquizando-o e afastando das concepções de "normalidade". O ápice deste

\footnotetext{
${ }^{22}$ Neste item, uma ressalva: o plenário afastou a necessidade de determinação judicial para alteração de registro, todavia, alguns ministros entenderam a necessidade de comprovação jurídica de sua condição para obter mudança de registro. Aqui se afiliaram os ministros Alexandre de Moraes, Dias Toffoli e Gilmar Mendes, que ficaram vencidos.

${ }^{23}$ ADIO n ${ }^{\circ} .26$ de 2013. Disponível em: <https://jurisprudencia.stf.jus.br/pages/search/sjur433180/false>. Acesso em 15 de outubro de 2020

${ }^{24}$ Inclusive, o relator, ministro Celso de Mello, entendeu a homofobia e transfobia como qualificadoras agravantes na hipótese de homicídio doloso por configurar motivo torpe (Código Penal, art. 121, § 2 I).

${ }^{25}$ A Câmara dos Deputados respondeu, afirmando não ser verídica a informação, pela existência de 17 projetos de lei, desde 1997. Obviamente, todos em longa tramitação sem qualquer tipo de análise.

${ }^{26}$ Lésbicas, Gays, Bissexuais, Transgêneros e Intersexuais. Todavia, o ministro entende da seguinte forma: "a primazia conferida ao uso desse termo decorre, exclusivamente, do prestígio e do renome que o acrônimo LGBT adquiriu no âmbito da defesa dos direitos humanos e do combate à discriminação, sem que o seu emprego signifique indiferença ou esquecimento em relação às demais siglas também utilizadas, especialmente com o propósito de fazer incluir, em sua definição, as pessoas que se identificam como "queer" (LGBTQ), as pessoas intersexuais (LGBTQI), as pessoas assexuais (LGBTQIA) e todas as demais pessoas representadas por sua orientação sexual ou identidade de gênero (LGBTQI+)". Ver em ADIO 26, 2013, p. 42.
} 
processo conjuga exclusão de ordem política e de natureza jurídico-social. Neste sentido, há de ser apontada a repressão penal ${ }^{27}$. Neste caso, defende o ministro, tolerância e proteção constitucional se evidenciam como mecanismos protetivos que afastem os discursos de ódio da lógica destes dois mecanismos. Edson Fachin, em seu voto nesta ADIO, corrobora destacando que "a Constituição não autoriza tolerar o sofrimento que a discriminação impõe” (ADIO 26, 2013, p. 197).

O segundo elemento criticador por Celso de Mello é a criação de mecanismos sem funcionalidade, ou seja, a elaboração de preceitos constitucionais sem motivação de cumprimento. Portanto, a ADIO vem gerar legítima reação jurisdicional a "neutralizar gestos de desprezo pela Constituição, a outorgar proteção a princípios, direitos e garantias nela proclamados" (ADIO 26, 2013 , p. 9). Isso é visto quando a ação ajuizada é atestada pelo ministro como processo em que a indiferença se mostra o comportamento do legislador em relação à vulnerabilidade de grupos sociais no que toca às "graves ofensas perpetradas contra seus direitos fundamentais, essencialmente caracterizadas por atos de violência física e moral” (ADIO 26, 2013, p. 37). O ministro Luiz Fux desenvolve esta questão asseverando que a criação destes tipos penais às condutas discriminatórias se vincula à defesa da normatividade dos direitos fundamentais para proteger minorias políticas e preservar a abertura dos canais estruturais de participação política (ADIO 26, 2013, p. 411)

Curioso notar que, a partir do momento em que a ADIO 26 foi anunciada para julgamento, houve tentativa de manobra parlamentar para suspensão do julgamento ${ }^{28}$. Foi apresentado ao plenário do STF em 23 de maio de 2019, um Projeto de Lei no 2.672, de maio desse ano, de autoria do parlamentar Pastor Marco Feliciano ${ }^{29}$, solicitando suspensão do julgamento, tendo em vista apresentação de lei que comprovaria a não morosidade do Congresso Nacional em legislar. Celso de Mello, o relator da ADIO, entendeu este processo como manobra legislativa que não retirava o mérito do julgamento, considerando que o Congresso tinha mais de sete projetos de lei, muitos deles apresentados no mesmo regime de urgência que o PL $\mathrm{n}^{\circ} 2.672$, portanto, a iniciativa do parlamentar era meramente protelatória.

O ministro Alexandre de Moraes ratifica a posição de que, mesmo com a existência de políticas públicas de prevenção e combate às condutas transfóbicas e homofóbicas ${ }^{30}$, isto "não afasta a omissão constitucional, em face da exigência de proteção legal satisfatória contra atentados discriminatórios aos direitos e liberdades fundamentais praticados em virtude de orientação sexual e identidade de gênero" (ADIO 26, 2013, p. 245). A identidade de gênero ${ }^{31}$ ou orientação sexual são os conceitos que movem o pleito do desrespeito constitucional aos direitos fundamentais. Os ministros Alexandre de Moraes, Celso de Mello, Edson Fachin e Roberto Barroso subscrevem a o sexo como condição física e gênero como autopercepção do indivíduo, cuja associação ao sentimento de pertencimento aos elementos feminino, masculino, ou a nenhuma dessas definições tradicionais, constrói a percepção.

O resgate do reconhecimento da responsabilidade civil objetiva do Poder Público se dá confrontando à sua própria omissão deliberada em escrever e garantir direitos. Notadamente, a

\footnotetext{
${ }^{27} \mathrm{O}$ exercício da liberdade religiosa não é afetado neste caso. Celso de Mello entende que a repressão penal à prática da homotransfobia não alcança nem restringe ou limita o exercício da liberdade religiosa. Mesmo assim, ainda há falta de entendimento sobre o que é professado nas instituições religiosas ser passível de repressão penal.

${ }^{28}$ Ver nas páginas 312 a 314.

${ }^{29}$ Parlamentar da chamada "Bancada Evangélica", contrário à legislação garantista de direitos aos homossexuais.

${ }^{30}$ O termo "homofobia" é um neologismo derivado, na década de 1970, por "homo" que designa "igual" e "phobia" que corresponde à ideia de medo, contudo, a construção do termo é negativa, para reduzir o termo "homossexual". Ver em Weinberg (1972).

${ }^{31}$ Entendida por Celso de Mello como "A identidade de gênero, nesse contexto, traduz o sentimento individual e profundo de pertencimento ou de vinculação ao universo masculino ou feminino, podendo essa conexão íntima e pessoal coincidir, ou não, com a designação sexual atribuída à pessoa em razão sua conformação biológica" (ADIO 26, 2013, p. 44). Celso de Mello se prende à concepção binária de gênero, contudo, há de se considerar um avanço, ao menos na terminologia adotada pelo ministro em seu voto. O relator ainda discorre sobre "ideologia de gênero", em crítica direta aos que utilizam este termo. Contudo, não trataremos disso neste trabalho.
}

Revista de Direito Brasileira | Florianópolis, SC | v. 28 | n. 11 | p.131-163 | Jan./Abr. 2021 
batalha em se ter o direito a ter direitos se faz presente quando indivíduos precisam provar que são dignos de serem considerados sujeitos morais, políticos e civis em dada sociedade e frente aos ordenamentos constitucionais, quando não, comprovar que são "dignos" da proteção jurídica, portanto, o direito a ser considerado um sujeito de direitos e, consequentemente, portador de direitos $^{32}$. Ao mesmo tempo, o direito a ter direitos no âmbito dos LGBTI+ é uma frente de luta contra sistemas heternormativos, heretossexistas e cisgêneros, cuja norma social, política, econômica e jurídica protege e privilegia os ocupantes da norma rebaixando os "desviantes" 33 .

Diz Celso de Mello que "a liberdade e a autenticidade de cada ser humano constituem valores revestidos de inquestionável essencialidade", logo, privar alguém de viver sua identidade de gênero é "significaria privá-lo de uma dimensão fundamental da sua existência" (ADIO 26, 2013, p. 52). Ao mesmo tempo, deve-se combater o estigma da "diferença" associado à uma ideologia segregacionista, cuja intolerância não deve ser admitida. Portanto, há de se modificar os valores que estruturam a ordem democrática "que exaltam e reafirmam a superioridade ética dos direitos humanos" (ADIO 26, 2013, p. 189). Neste ponto, o papel do Poder Judiciário se mostra crítico quanto a assegurar direitos que são negligenciados nas práticas sociais e institucionais ${ }^{34}$.

Mais grave é quando o próprio Estado, que se considera Estado de Direito, cria mecanismos que segregam ou em que abstém o Estado de decidir pela garantia de direitos, como apontam os ministros Edson Fachin ${ }^{35}$ e Alexandre de Moraes $^{36}$. Neste ponto, quando se observa que direitos fundamentais vêm sendo negligenciados a grupos minoritários, se abre possibilidade de criação de tipos penais próprios à devida proteção ${ }^{37}$. O ministro Luiz Fux complementa, situando que "o reconhecimento da criminalização das condutas [...] altera a cultura do povo não só por força dessa imprescritibilidade [...] ela aumenta a autoestima dessa minoria e lhes conforta com a sensação de pertencimento à sociedade"38 (ADIO 26, 2013, p. 407). O argumento final é trazido pelo ministro Ricardo Lewandowski, em que a ideia de que legislações em que ocorram tipificação penal de condutas discriminatórias do tipo homofóbicas e transfóbicas, além de representar avanço

\footnotetext{
32 Esta discussão está delimitada nos trabalhos de Arendt (1979).

33 Ver Vecchiatti (2017) para compreender como estas normas constroem sistemas excludentes, sobretudo, contra LGBTI+. O autor, inclusive, a partir das obras de Hannah Arendt, entende os crimes de homofobia e transfobia como gravíssima realidade contemporânea como expressão da banalidade do mal homofóbico e transfóbico.

${ }^{34}$ Contudo, existem críticas quanto à legitimidade democrática do Poder Judiciário em legislar diante de "omissão" do Poder Legislativo. Considera-se que lhe falta, primeiramente, competência para tal, e, sem segundo, atribuição constitucional para a criação do arcabouço normativo. Ainda: a questão democrática é fator relevante, por membros do judiciário não serem representantes eleitos pela população, cuja Agenda moral e política estão associadas no voto. Ver esta discussão em Tushnet (1999).

${ }^{35}$ Diz o ministro: "É atentatório ao Estado Democrático de Direito qualquer tipo de discriminação, inclusive a que se fundamenta na orientação sexual das pessoas ou em sua identidade de gênero" (ADIO 26, 2013, p. 197).

${ }^{36}$ Diz o ministro: "Sob essa perspectiva de proteção igualitária e sem discriminações de todos os sujeitos de direitos e garantias fundamentais, acentua-se a necessidade de conjugarem-se e compatibilizarem-se as ideias de Democracia, que se manifesta basicamente pela forma representativa, por meio dos Parlamentos, e de Estado de Direito, que se manifesta pela consagração da supremacia constitucional e o respeito aos direitos fundamentais, tornando-se, portanto, clara a legitimidade da Justiça constitucional e a necessidade de existência de seus órgãos, dotados de plena independência e que possam instrumentalizar a proteção dos preceitos e direitos constitucionais fundamentais" (ADIO 26, 2013, p. 255-256).

${ }^{37}$ A questão de que não se pode negligenciar preceitos dos direitos fundamentais, em que grupos são violentados, pois acatar a Constituição segundo as próprias inclinações em detrimento alheio é tornar o texto uma letra morta. Ver este desenvolvimento em Gonçalves (2007, p. 303-310).

38 Medidas jurídicas de reconhecimento de direitos a grupos negligenciados não são isentos de resistência e contestação. Pode existir, e existirá, alguma concepção de soma-zero na política: em que grupos "ganham" direitos em detrimento de outros. Porque quando estes grupos "ganham" direitos, ganham às "custas" da sociedade, pelo rompimento de bases "normais" que sustentam este contexto. Não é à toa que estas medidas definidas por Cortes Superiores são sempre acompanhadas pelo reforço da tolerância e respeito aos grupos. A compreensão políticonormativa por trás é que democracia não é sinônimo de maioria, tal como em uma tirania, pelo contrário, a democracia exige defesa de minorias e compreensão da diferença como parte. Tal questão é desenvolvida por Brown (2009) e Ely (1980).
} 
civilizatório e reconhecimento moral, legal e institucional, situam a conjugação de categorias de orientação sexual e identidade de gênero aos chamados crimes de ódio ${ }^{39}$ (ADIO 26, 2013, p. 510).

\subsection{Habeas Corpus 152.491 São Paulo de 2018}

O pedido de Habeas Corpus 152.491 de São Paulo de $2018^{40}$ tratava de paciente condenado à pena de 6 (seis) anos de reclusão, em regime inicial fechado, pelo crime previsto no artigo 158, $\S 3^{\circ}$, do Código Penal, vedado o direito de recorrer em liberdade. O paciente em questão é relatado como travesti pelos advogados em citação do relator do HC, ministro Roberto Barroso. O pedido solicitava o aguardo em liberdade ou a transferência à uma penitenciária feminina, indicando que "a despeito de sua opção sexual, está presa em uma cela com 31 homens, quando a capacidade é apenas 12” (HC 152.491, 2018, p. 4).

Interessante registrar o uso do termo "opção sexual" e não "identidade de gênero" pelos advogados. Contudo, mais à frente, decisão do juiz de primeira instância destaca o uso do termo "transexual", em vez de "travesti" incialmente pelos advogados. O destaque da decisão judicial aponta que o acusado é transexual que se vale de programas e que, em um destes, teria utilizado de grave ameaça com arma branca para obter vantagem. O juízo ainda cita elementos morais, em que "a repetição de condutas delituosas pelos acusados, evidencia personalidade distorcida por inclinação irreversível para o crime. E, nesse sentido, sua segregação cautelar é medida que se impõe para a garantia da ordem pública" (HC 152.491, 2018, p. 5).

O relator, Roberto Barroso, entende que, na linha da Resolução Conjunta $n^{\circ}$ 1, de 15.04.2014, do Conselho Nacional de Combate à Discriminação; e da Resolução da Secretaria de Administração Penitenciária $n^{\circ} 11$, de 30.01.2014, do Estado de São Paulo, "a notícia de que o paciente e o corréu foram incluídos em estabelecimento prisional incompatível com as respectivas orientações sexuais autoriza a concessão da ordem de ofício" (HC 152.491, 2018, p. 5), todavia, o ministro não concede o habeas corpus, mas determina transferência à estabelecimento prisional compatível com as respectivas orientações sexuais. Neste ponto, mais uma vez o entendimento de "orientação sexual" se torna sinônimo de "identidade de gênero".

Convém situar que a questão de transexuais em sistemas prisionais não é questão pacífica no contexto jurídico, político, legal ou social. Há uma série de confrontos a respeito do debate entre feministas abolicionistas, liberais e radicais. As feministas abolicionistas defendem o fim do sistema de encarceramento, sobretudo de negros e pobres. Já o maior confronto, do ponto de vista feminista é entre as duas últimas. As feministas radicais ${ }^{41}$ entendem que pode ter um conflito de homens se utilizarem de processos de transgeneridade para obterem "vantagens" e serem realocados para estabelecimentos femininos, onde representariam perigos às mulheres. Já as feministas liberais ${ }^{42}$ seguem raciocínio de respeito à identidade de gênero em que transexuais devem ter o direito a estarem em estabelecimentos prisionais adequados à sua identidade de gênero.

\footnotetext{
${ }^{39}$ Para Libby Adler (2018, p. 121-125), a lei que cria tipificação penal aos crimes de ódio associados à discriminação por orientação sexual e identidade de gênero apontam mensagem clara de inaceitabilidade da violência exigindo mudança cultural. Não obstante, são demandas mais ações de caráter informativo, preventivo e de combate à discriminação não violenta fisicamente.

${ }^{40}$ HC 152.491. Disponível em: 〈http://portal.stf.jus.br/processos/detalhe.asp?incidente=5341940〉. Acesso em 15 de outubro de 2020.

${ }^{41}$ A ideia de que homens possam manipular o sistema prisional utilizando da transgeneridade é própria do feminismo radical. Ao mesmo tempo, quando há a mudança de sexo, homens que se tornam mulheres transexuais possuiriam vantagens inerentes à sua condição masculina, a qual, não se abre mão e fazem parte do uso de estratégias para caricaturar uma forma feminina que lhes dê vantagens que não são próprias às mulheres. No contexto prisional, esta brecha seria um elemento jurídico em que homens se utilizariam da transgeneridade para mudarem de estabelecimento prisional, onde ameaçariam mulheres e as colocaria em risco. Ver em Jeffreys (2014).

42 As feministas radicais parecem afastar a ideia de pessoas transexuais sofrem violência direta por estarem em estabelecimento prisional incompatível com sua identidade de gênero. $\mathrm{O}$ contexto argumentado pelas radicais é o do homem perigoso e violador de mulheres. Quando uma mulher transexual surge em estabelecimento prisional, a ideia Revista de Direito Brasileira | Florianópolis, SC | v. 28 | n. 11 | p.131-163 | Jan./Abr. 2021
} 
O que é afastado do debate é que o sistema prisional deve ter a salvaguarda de Direitos Humanos e não se tornar um depósito de indivíduos despersonalizados de direitos e integridade quanto ao corpo e ao respeito de si. A ideia preponderante nos debates é o de que um espaço como a prisão não é alcançado pela dignidade (até pelo fato de que os que estariam ali, teriam aviltado justamente os preceitos da dignidade de outros). Portanto, uma terra morta, sem espaço para regras, autônoma e regulada pela "ordem" local. Esse sujeito despersonalizado de direitos na prisão não seria moralmente reconhecido como alguém que deveria ter um direito respeitado, dentre eles, a identidade de gênero.

\subsection{Medida cautelar na arguição de descumprimento de preceito fundamental 527 Distrito Federal}

A medida cautelar na Arguição de Descumprimento de Preceito Fundamental 527 do Distrito Federal ${ }^{43}$ tem como controvérsia acerca das unidades prisionais e demais condições em que deve ocorrer o cumprimento de pena de transexuais e travestis e sua possibilidade de assegurar que transexuais femininas cumpram pena em presídio feminino. A dúvida recaia, pelo fato de o requerente se afirmar travesti e a norma indicava a possibilidade de transexuais estarem em estabelecimentos prisionais adequado ao se gênero.

Para o relator, ministro Roberto Barroso, "Transexuais e travestis encarceradas são, assim, um grupo sujeito a uma dupla vulnerabilidade, decorrente tanto da situação de encarceramento em si, quanto da sua identidade de gênero", sendo "pessoas ainda mais expostas e sujeitas à violência e à violação de direitos que o preso comum" (MC na ADPF 527, 2020, p. 9). A questão, portanto, é que, diferentemente de transexuais, não há a mesma clareza quanto ao tratamento a ser conferido às travestis. A ADPF ainda não foi julgada, contudo o relator determinou que apenas "transexuais femininas sejam transferidas para presídios femininos" e que seja discutido na corte a possibilidade de escolha para transexuais, de acordo com sua identidade de gênero.

\subsection{Recurso extraordinário 845.779 Rio Grande do Sul de 2014}

O Recurso Extraordinário 845.779 de Santa Catarina ${ }^{44}$ versava sobre proibição de uso de banheiro feminino em shopping center por pessoas transexuais. A controvérsia era sobre se uma pessoa pode ou não ser tratada socialmente como se pertencesse a sexo diverso do qual se identifica e se apresenta publicamente. Em decisão do Tribunal de Justiça de Santa Catarina negou reconhecimento do dano moral pelo impedimento de acesso ao banheiro feminino local, alegando discriminação praticada por seguranças do local em razão de ser transexual sob o argumento de que sua presença causaria constrangimento às usuárias do local. O julgamento foi paralisado em 4 de maio de 2016, estando até outubro de 2020 aguardando vistas do ministro Luiz Fux.

A controvérsia jurídica é decorrente do fato de a pessoa transexual ser psicossocialmente identificada como mulher, mas sem ter o devido registro civil alterado. E se a abordagem à transexual para utilizar banheiro do sexo oposto ao qual se dirigiu primeiramente, configura ou não conduta ofensiva à dignidade da pessoa humana e a direitos da personalidade. $\mathrm{O}$ relator, Luis Roberto Barros, ao tentar conceituar transexualidade, apela à definição do catálogo da CDI com

do homem violador ressurge e se desconsidera que ali está um corpo compreendido como feminino que sofre interpretações que mesclam ojeriza, desrespeito e legitimação moral (pelo violador) de restabelecimento da ordem constituída no sexo de nascimento, logo, a violência é eminente e esperada quando uma pessoa transexual adentra estabelecimento prisional incompatível. Ver em Erickson-Schroth (2014).

${ }^{43} \mathrm{MC}$ na ADPF no. 527 de 2018. Disponível em: <http://portal.stf.jus.br/processos/detalhe.asp?incidente=5496473>. Acesso em 15 de outubro de 2020

${ }^{44} \mathrm{RE} \mathrm{n}{ }^{\circ} 845779$ de 2013. Disponível em: <https://jurisprudencia.stf.jus.br/pages/search/repercussao-geral7101/false>. Acesso em 15 de outubro de 2020.

Revista de Direito Brasileira | Florianópolis, SC | v. 28 | n. 11 | p.131-163 | Jan./Abr. 2021 
base no "transexualismo" apontando o "desejo de viver e ser aceito como um membro do sexo oposto", colocando como constitucional "se uma pessoa pode ou não ser tratada socialmente como se pertencesse a sexo diverso do qual se identifica e se apresenta publicamente" (RE 845.779, 2014, p.9-10), considerado, inclusive o conteúdo jurídico do direito à autodeterminação sexual.

Desde 2016 este recurso aguarda julgamento no STF. O relator, Luís Roberto Barroso e o ministro Edson Fachin aceitaram e deram provimento ao recurso, entendendo que existiu dano moral em flagrante discriminação transfóbica que atentava quanto aos direitos à personalidade. Ainda assim, é nítido que uma corte constitucional que demore em 4 anos um pedido de vista para considerar se é inconstitucional o impedimento de transexuais utilizarem o banheiro que melhor apraz à sua identidade de gênero é mais uma forma de afastar o direito de pessoas transexuais.

\section{MOBILIZANDO GÊNERO NA COMPREENSÃO SOCIOJURÍDICA}

A categoria "gênero" é a categoria que perpassa as decisões judiciais que envolvem reivindicações de direitos para pessoas trans, assim como para seu impedimento. É preciso mobilizar a categoria para realizar dois movimentos: 1) associar sexo e gênero, como interdependentes em construção social que não hierarquiza sujeitos; ou 2) dissociar sexo e gênero, apagando a segunda, e construindo categoria unicamente biológica e determinista sobre o sexo na dicotomia homem/mulher e macho/fêmea com seus respectivos cumprimentos de papeis. Enquanto o primeiro movimento sensibiliza sobre diferentes formas de identidade de gênero e orientação sexual, desafiando textos normativos que delimitam direitos originados na binaridade de gênero, ampliando-os para abranger novas intepretações, o segundo movimento reforça a base interpretativa que delimita a concepção original.

Percebe-se que as ações judiciais, tanto no Brasil, quanto nos Estados Unidos, desafiam a hermenêutica do intérprete legal para se atentar à evolução conceitual de concepções sobre o gênero e sexo que foram inscritas em instrumentos normativos não mais condizentes às épocas em que foram delimitados. Susan Okin pondera que o uso da categoria "gênero" implica argumentação que incide sobre processo separatório e recupera a simbiose dos conceitos esfera pública e esfera privada. Para a autora, "gênero" se refere à "institucionalização social das diferenças sexuais", sendo apreendido tanto pela desigualdade sexual assim como das diferenciações sexuais socialmente construídas. Em paralelo, como o "gênero" perpassa elementos históricos, políticos, socioeconômicos e psicológicos (OKIN, 2008, p. 319).

Vemos estas diferenças sexuais como erguidas a partir de diferenças que são estigmatizadas ou subordinadas em lógica de superioridade da figura masculina. Neste contexto, onde os homens servem como referencial político da ordem dos direitos, vemos que os mesmos se tornam basilares ao sistema dos direitos individuais via concepção moderna de liberdade - os indivíduos referenciais reificados aqui são masculinos (OKIN, 2008). Portanto, a leitura moral do intérprete desafia as concepções masculinizantes que evidenciaram dualidade homem/mulher e macho/fêmea de categorias reificantes do "gênero".

Scott (2018) destaca que feministas da década de 1980 usaram a categoria "gênero" para rejeitar o determinismo biológico implícito no uso do sexo ou diferença sexual, ainda que, inicialmente, se associasse "gênero" a definições normativas de feminilidade, assim como usado como potencial à quebra de paradigmas disciplinares pela escolarização das mulheres. O "gênero" como categoria analítica impõe articular sujeito individual com organizações sociais ao entendimento da natureza de seus inter-relacionamentos, igualmente, o funcionamento do gênero e a ocorrência de mudanças. Para Scott (2018), gênero é elemento constitutivo de relações sociais baseadas em distintas percepções entre os sexos, ao passo em que gênero é o caminho primário em dar significado às relações de poder.

Assim podemos compreender que os magistrados que entenderam por efetivar os direitos de pessoas trans se dá pela leitura ampliada do gênero como instância socialmente construída junto 
ao sexo, interdependentes, subscrevendo que direitos firmados na leitura binária deve ser reescrita afim de ter a interpretação mais abrangente da regra, sem criar novos direitos, mas efetivas para estas pessoas negligenciadas, um direito que já é usufruído por outrem. O impedimento do usufruto dos direitos se dá pela leitura estática de concepção de gênero e sexo não mais condizente à mudança da sociedade. Aqui decorre o segundo movimento: correlacionar gênero, sexo e desigualdade.

Hunt destaca a dinamicidade dos Direitos Humanos, ao situar que permanecem em constante discussão pelas díspares percepções sobre o que são e quem deve deter tais direitos. Nesta seara, sentimentos e anseios podem construir coordenação e mobilização política pautados na empatia, permitindo novas interpretações sobre igualdade do sujeito de igual valor moral, cuja potência é a mesma que de seus semelhantes. Constrói-se, assim, um mundo moral que observa a todos, considerando o outro como seu igual em termos de aprendizado (HUNT, 2007).

O uso de estereótipos e características para hierarquizar, segregar e marginalizar norteiam a diferença como elemento discriminatório (BARROS, 2016) que acaba derivando um grupo político hegemônico que dita normas e direitos (DAVIS, 1983) capazes, inclusive, de erguer estruturas de opressão (YOUNG, 2011). A diferença se torna, assim, elemento político que orienta a estrutura sociojurídica, político-econômica e institucional que diferenciam pessoas por dentro e de forma chancelada pelo Estado. Estas pessoas seriam subcidadãos (quando algum direito é reconhecido) ou simplesmente marginalizadas em uma estrutura opressiva. O que vemos, tanto nos Estados Unidos, quanto no Brasil, são interpretações morais das respectivas constituições que situam a integridade como concepção de dignidade humana relacionada à responsabilidade, autorrespeito e autenticidade, permitindo que cada pessoa viva conforme seus próprios termos e usufruindo de direitos que já são exercidos por outros.

Gênero e sexo mobilizam, junto à desigualdade, a possibilidade da compreensão do desenvolvimento da discriminação como elemento político que orienta agendas distributivas de reconhecimento de direitos (FRASER, 2013), evidenciando a negligência e a marginalização como sofrimentos que indeterminam sujeitos. Honneth (1995) aponta que o não reconhecimento intersubjetivo é parte de processo que induz sofrimento capaz de indeterminar as pessoas no mundo e em suas próprias relações sociais, impedindo relações de direitos e de demandas sociais relativas aos direitos.

O movimento realizado, portanto, é demonstrar, ao intérprete, o contexto em que sexo e gênero constroem bases que rebaixam sujeitos a viverem em condições inferiores e inseguras em todas as esferas da vida, quando interpretado à luz de lógicas binárias de homem/mulher biologicamente estanques. O movimento envolve tornar a concepção de gênero e sexo fluidas, relacionando-as às modificações da sociedade, afim de reescrever as concepções normativas escritas na binaridade.

O terceiro, e último movimento, consequentemente, é reescrever a base normativa que serve de interpretação aos litígios. Como se trata de reescrita em bases mais fluidas e não estanques, tem-se um texto com interpretação mais abrangente das regras, o que permite, inclusive, relacionar este direito associado, a outros que tenham possível relação com a controvérsia originada. Por exemplo, tendo em vista o reconhecimento do direito às pessoas trans a alterarem seu registro civil sem necessidade de redesignação sexual, permite a obtenção de direitos derivados, uma vez que o registro civil envolve uma série de prerrogativas de bens e serviços.

Tendo em vista a técnica de Análise de Conteúdo vista em Bardin (1977), é possível categorizar estes movimentos de forma sucinta e estratégica à compreensão. Separamos três profundidades de categorização a partir do seguinte processo metodológico: iniciais (que partem o processo), intermediárias (que intermedeiam junto às iniciais) e finais (que constroem o sentido). A primeira categoria envolve a mobilização do "gênero" e a "desigualdade/diferença", as categorias intermediárias envolvem as reivindicações políticas e jurídicas no sistema social e a categoria final envolve o objeto sistematizado da reivindicação. Veja na Tabela 1. 
ADI 4.275 mobiliza categorias para além da binaridade homem/mulher, inclusive, desloca de "transexual" para "transgênero", uma vez que o termo "transexual" ainda trabalha nas categorias homem/mulher e, poderia, igualmente, ser interpretado em viés biológico, portanto, o termo "transgênero" mobiliza para compreensão social que interpela tanto o sexo quanto o gênero, permitindo interpretação mais fluida. Do mesmo modo, nesta ADI se percebe uma tentativa da Corte em evidenciar a efetiva garantia de direitos, afastando que diferenças sejam incorporadas como delimitadoras de direitos de segunda categoria, no exemplo de se afastaa a necessidade de redesignação cirúrgica para reconhecimento civil. Por fim, a Identidade ou expressão de gênero é mobilizador da Dignidade da pessoa humana.

A ADIO 26 tratava de criminalização de práticas homofóbicas e transfóbicas, portanto, mobiliza as categorias da "homossexualidade" e "transexualidade", considerando que estas categorias seriam interpretadas como diferenças que não podem deixar brechas legais abertas de omissão quando o próprio Estado, que se considera Estado de Direito, cria mecanismos que segregam ou em que abstém o Estado de decidir pela garantia de direitos. Mobilizar as categorias "homossexualidade" e "transexualidade" afim de criação de proteção legal é enfrentar sistemas heternormativos, heretossexistas e cisgêneros evocando a responsabilidade civil objetiva do Poder Público de igualdade.

O HC 152.491 mobiliza, inicialmente, a categoria "travesti", quando da apelação dos advogados, contudo, a decisão do juiz escreve a categoria "transexual" em sua decisão, não estando claro se foi erro ou interpretação do magistrado. De certo, as categorias "orientação sexual" e "identidade de gênero" são elementos sensibilizadores da decisão do magistrado. Em suma, a categoria é mobilizada pelo fato do não respeito à uma pessoa com determinada identidade de gênero informada não estar no devido estabelecimento prisional adequado. Portanto, A identidade de gênero é mobilizada como resgate à despersonalização de direitos na prisão, como uma forma de salvaguardar Direitos Humanos e não tornar a prisão um depósito de indivíduos despersonalizados.

O RE 845.779 trata do caso de transexual ser proibida do uso de banheiro feminino, mobilizando a categoria "transexualidade", onde a requerente afirma o desejo de viver e ser aceito como um membro do sexo oposto, e de ser tratada socialmente como se pertencesse a sexo diverso do qual se identifica e se apresenta publicamente. A diferença é mobilizada como um mecanismo de direito à autodeterminação sexual e respeito à personalidade. 
Tabela 1. Categorias envolvidas na mobilização de direitos de pessoas trans.

\begin{tabular}{|c|c|c|c|c|c|}
\hline \multirow{3}{*}{ Processo } & \multicolumn{5}{|c|}{ Mobilização de categorias } \\
\hline & \multicolumn{2}{|c|}{ Iniciais } & \multicolumn{2}{|c|}{ Intermediárias } & \multirow[t]{2}{*}{ Final } \\
\hline & Gênero & $\begin{array}{c}\text { Desigualdade e/ou } \\
\text { diferença }\end{array}$ & Político & Jurídico & \\
\hline $\begin{array}{c}\text { ADI } 4.275 \\
\text { e } \\
\text { RE } \\
670.422\end{array}$ & $\begin{array}{c}\text { De Transexualidade } \\
\text { para } \\
\text { Transgeneridade }\end{array}$ & $\begin{array}{l}\text { Diferenças não } \\
\text { podem criar } \\
\text { direitos de } \\
\text { segunda categoria }\end{array}$ & $\begin{array}{l}\text { Identidade ou } \\
\text { expressão de } \\
\text { gênero }\end{array}$ & $\begin{array}{c}\text { Dignidade da } \\
\text { pessoa humana }\end{array}$ & \\
\hline ADIO 26 & $\begin{array}{l}\text { Homossexualidade } \\
\text { e Transsexualidade }\end{array}$ & $\begin{array}{l}\text { Diferenças não } \\
\text { podem deixar } \\
\text { brechas legais } \\
\text { abertas de } \\
\text { omissão }\end{array}$ & $\begin{array}{l}\text { Enfrentamento a } \\
\text { sistemas } \\
\text { heternormativos, } \\
\text { heretossexistas e } \\
\text { cisgêneros }\end{array}$ & Proteção legal & $\begin{array}{c}\text { Responsa } \\
\text { bilidade } \\
\text { civil } \\
\text { objetiva } \\
\text { do Poder } \\
\text { Público }\end{array}$ \\
\hline $\begin{array}{c}\mathrm{HC} \\
152.491 \mathrm{e} \\
\mathrm{MC} \text { na } \\
\text { ADPF } 527\end{array}$ & $\begin{array}{l}\text { De Travestilidade } \\
\text { para } \\
\text { Transexualidade }\end{array}$ & $\begin{array}{l}\text { A identidade de } \\
\text { gênero como } \\
\text { resgate à } \\
\text { despersonalização } \\
\text { de direitos na } \\
\text { prisão }\end{array}$ & $\begin{array}{l}\text { "orientação } \\
\text { sexual" } \\
\text { "identidade de } \\
\text { gênero" como } \\
\text { elementos } \\
\text { sensibilizadores }\end{array}$ & $\begin{array}{c}\text { salvaguarda de } \\
\text { Direitos Humanos } \\
\text { e não se tornar um } \\
\text { depósito de } \\
\text { indivíduos } \\
\text { despersonalizados }\end{array}$ & \\
\hline $\begin{array}{c}\mathrm{RE} \\
845.779\end{array}$ & Transexualidade & $\begin{array}{l}\text { desejo de viver e } \\
\text { ser aceito como } \\
\text { um membro do } \\
\text { sexo oposto }\end{array}$ & $\begin{array}{c}\text { ser tratada } \\
\text { socialmente como } \\
\text { se pertencesse a } \\
\text { sexo diverso do } \\
\text { qual se identifica } \\
\text { e se apresenta } \\
\text { publicamente }\end{array}$ & $\begin{array}{c}\text { direito à } \\
\text { autodeterminação } \\
\text { sexual }\end{array}$ & \\
\hline
\end{tabular}

Fonte: elaborador pelo autor a partir de Bardin (1977).

O que está demonstrado, como se vê, é a responsabilidade civil objetiva do Poder Público de efetivar direitos, quando sujeitos indicam não serem considerados de igual valor moral na sociedade. Esta reivindicação não pode ser confundida, como geralmente o é por grupos conservadores, em uma lógica de "criação de novos direitos". Na argumentação de grupos conservadores, valores familiares são elementos para situar uma lógica de atentado contra a sociedade ou "novos direitos" que "privilegiaram" grupos minoritários a terem direitos. A questão em tela é que a maioria da população já exerce estes direitos, ao contrário de pessoas trans.

Ao mesmo tempo, não se trata de um "ativismo judicial" que colocaria o Poder Judiciário em contexto criador de leis. Até porque não se estão criando novas leis, mas abrangendo a grupos que não são alcançados pelas leis sem seu texto original. O Judiciário não pode estar omisso de seu papel de interpretar as leis, neste caso, de forma abrangente. Há aqueles, dentro do Judiciário que defendem a ideia de que a interpretação deve ser minimalista, restrita ao que está devidamente escrito. Mas esta posição está presa à uma concepção datada historicamente de Sociedade e Direito que não necessariamente são condizentes à representação da sociedade. A maioria deve ditar os critérios dela para atender à toda sociedade, afastando grupos minoritários de participação na mesma? Neste processo, grupos minoritários recorrem às instâncias estatais para reivindicar.

Nos recorda Peres (2013, p. 301) que em conjunturas peculiares, a arena jurídica pode ser provocada a decidir sobre reivindicações de grupos minoritários. A esfera jurídica é última alternativa após grupos minoritários perceberem que as instâncias legislativas não irão discutir mudanças legais. Todavia, há de se considerar o papel limitante do Judiciário, não sendo considerado como capaz de reescrever direitos e promover mudanças sociais, mesmo com negligência do Executivo ou Legislativo (WILSON \& GIANELLA-MALCA, 2019; KMIEC, 2004; TATE \& VALLINDER, 1995; COHN \& KREMNITZER, 2005). 
Por outro lado, é fato que, nesta flagrante desconsideração de direitos, é por via judiciária que ocorre efetivação de direitos, ainda mais quando evidenciados o alto grau de vulnerabilidade dos grupos sociais afetados (CENZIPER \& OBERGEFELL, 2016). Por isso o Judiciário vem tomando protagonismo recente, sobretudo na América Latina em resguardar e ampliar direitos a esses grupos vulneráveis e marginalizados (CEPEDA ESPINOSA, 2004; UPRIMNY, 2007; WILSON, 2009). Não obstante, este processo também ocorre nos Estados Unidos, como foi apontado. Por fim, como ressalta Bunchaft (2013, p. 289), é preciso que a interpretação de conceitos seja à luz de como valores políticos afetam a estrutura normativa, assim, a compressão e concepção de Justiça, Democracia e Dignidade Humana não são conflitantes, nem autônomos, mas analisados e interpretados de forma integrada.

\section{CONSIDERAÇÕES FINAIS}

A reivindicação de direitos a partir de experiências trans no Brasil e nos Estados Unidos assumiu, ao menos a partir da segunda década do século XX, uma epopeia de reviravoltas, cujo mote é evidenciar a existência de pessoas. Trata-se, assim, de uma reivindicação ao direito a ter direitos. Qualquer reivindicação por direitos perpassa uma negligência ou fragilidade do usufruto - não é o caso de pessoas trans. O litígio indica a inexistência das pessoas trans como sujeitos de direitos, uma vez que a reivindicação é o mesmo tratamento dispensado à maioria da população (que serve como modelo normativo). Quando da negligência, inexistência ou fragilidade de direitos, urge a responsabilidade civil objetiva do Poder Público de efetivar direitos, quando sujeitos indicam não serem considerados de igual valor moral na sociedade. O reconhecimento de pessoas trans nas decisões judiciais no Brasil e Estados Unidos são desencadeados em três processos, a seguir comentados.

O primeiro processo envolve categoria "gênero", como categoria que perpassa as decisões judiciais que envolvem reivindicações de direitos para pessoas trans, assim como para seu impedimento. É preciso mobilizar a categoria para associar sexo e gênero, como interdependentes em construção social, sensibilizando sobre diferentes formas de identidade de gênero e orientação sexual, desafiando textos normativos que delimitam direitos originados na binaridade de gênero, ampliando-os para abranger novas intepretações, o segundo movimento reforça a base interpretativa que delimita a concepção original.

O segundo processo envolve correlacionar gênero, sexo e desigualdade. Neste processo, gênero e sexo mobilizam, junto à desigualdade, a possibilidade da compreensão do desenvolvimento da discriminação como elemento político, evidenciando a negligência e a marginalização de sujeitos. Portanto, o intérprete compreende o contexto em que sexo e gênero constroem bases que rebaixam sujeitos a viverem em condições inferiores e inseguras em todas as esferas da vida, quando interpretado à luz de lógicas binárias de homem/mulher biologicamente estanques. Os magistrados entendem que efetivar os direitos de pessoas trans se dá pela leitura ampliada do gênero como instância socialmente construída junto ao sexo, interdependentes, subscrevendo que direitos firmados na leitura binária deve ser reescrita afim de ter a interpretação mais abrangente da regra.

O terceiro, e último processo, consequentemente, é reescrever a base normativa que serve de interpretação aos litígios. Como se trata de reescrita em bases mais fluidas e não estanques, temse um texto com interpretação mais abrangente das regras, o que permite, inclusive, relacionar este direito associado, a outros que tenham possível relação com a controvérsia originada. Além disso, as categorias "gênero" e "sexo" são mobilizadas a conjugar a "identidade de gênero" e "orientação sexual" na interpretação abrangente de regras.

Pessoas trans demandam o reconhecimento de que podem e devem exercer os mesmos direitos e prerrogativas daqueles que exercem em maioria na sociedade. Trata-se de retirar a violência cometida pelo próprio Estado e suas estruturas sociais às pessoas trans. Esta reivindicação 
não pode ser confundida com a criação de "novos" direitos. Até porque não são direitos exclusivos criados para um pequeno grupo, mas a efetivação de direitos a este grupo, quando do exercício dos mesmos direitos pelos grupos mais representativos de uma sociedade. O Judiciário não está criando novas leis, nem assumindo papel ativista.

Por outro lado, mesmo que a via judiciária não seja capaz de reescrever direitos e promover mudanças sociais, mesmo com negligência do Executivo ou Legislativo, é por via judiciária que ocorre efetivação de direitos, ainda mais quando evidenciados o alto grau de vulnerabilidade dos grupos sociais afetados. É preciso, portanto, que a interpretação de conceitos seja à luz valores políticos congregando Justiça, Democracia e Dignidade Humana em perspectiva integrada, que permita sujeitos, antes excluídos, possam ser plenos em sua dignidade, em igualdade de direitos.

\section{REFERÊNCIAS}

ADLER, Libby. Gay Priori: A Queer Critical Legal Studies Approach to Law Reform. Durham: Duke University Press, 2018

ALBARRACÍN, Mauricio. Social Movements and the Constitutional Court: Legal Recognition of the Rights of Same-Sex Couples in Colombia. Sur: International Journal v. 8, n. 14, p. 7-31, 2011. Disponível em: <https://sur.conectas.org/en/social-movements-constitutional-court/>. Acesso em 8 de novembro de 2020.

AMARAL, Marília dos Santos et al. "Do travestismo às travestilidades": uma revisão do discurso acadêmico no Brasil entre 2001-2010. Psicologia \& Sociedade, v. 26, n. 2, p. 301-311, 2014. Disponível em: <http://www.scielo.br/scielo.php?script=sci_arttext\&pid=S0102$71822014000200007 \& \operatorname{lng}=$ pt\&nrm=iso $>$. Acesso em 22 de agosto de 2020

ARAÚJO, LUIZ HENRIQUE DINIZ. O ativismo judicial e constrangimentos a posteriori. Revista de Investigações Constitucionais, v. 5, n. 1, p. 129-150, 2018. Disponível em: $<$ http://www.scielo.br/scielo.php?script=sci_arttext\&pid=S2359$56392018000100129 \& \operatorname{lng}=$ en\&nrm=iso>. Acesso em 22 de agosto de 2020.

ARENDT, Hannah. The Origins of Totalitarism. 3rd edition. New York: Hancourt, Brace, and Jovanovich, 1979.

BARDIN, Laurence. Análise de Conteúdo. Tradução de Luís Antero Reto e Augusto Pinheiro. Lisboa: Edições 70, 1977.

BARROS, José D’Assunção. Desigualdade e Diferença: Construções históricas e imaginárias em torno da desigualdade humana. Petrópolis, RJ: Vozes, 2016.

BENHABIB, Seyla. Dignity in Adversity: Human rights in Troubled Times. Malden, MA and London: Polity Press, 2011.

BENTO, Berenice. A reinvenção do corpo: sexualidade e gênero na experiência transexual. Rio de Janeiro: Garamond, 2010.

BERG-WEGER, Marla (Editor). Social Work and Social Welfare: An Invitation. New York: Routledge, 2016. 
BRASIL. O Ministério Público e a Igualdade de Direitos para LGBTI. Conceitos e legislação. Brasília: MPF, 2017

BROWN, Wendy. Regulation Aversion: Tolerance in the age of identity and Empire. Princeton University Press, 2009.

BOURDIEU, Pierre. Masculine Domination. Translated by Richard Nice. Stanford, California: Stanford University Press, 2001.

BUNCHAFT, Maria Eugenia. A jurisprudência brasileira da transexualidade: uma reflexão à luz de Dworkin. Sequência, n. 67, p. 277-308, 2013. Disponível em: < https://www.scielo.br/scielo.php?script=sci_arttext\&pid=S2177-70552013000200011>. Acesso em 27 de outubro de 2020.

BUTLER, Judith. Gender Trouble: Feminism and the subversion of Identity. New York: Routledge, 1999.

CENZIPER, Debbie; OBERGEFELL, Jim. Love Wins: The Lovers and Lawyers Who Fought the Landmark Case for Marriage Equality. New York: HarperCollins, 2016.

CEPEDA ESPINOSA, Manuel José. Judicial Activism in a Violent Context: The Origin, Role, and Impact of the Colombian Constitutional Court. Washington University Global Studies Law Review v. 3, n. 4, p. 529-700, 2004. Disponível em:

<https://openscholarship.wustl.edu/law_globalstudies/vol3/iss4/2/>. Acesso em 10 de novembro de 2020 .

CHANTER, Tina. Gender: Key Concepts in Philosophy. Continuum: New York, 2007.

COHN, Margit; KREMNITZER, Mordechai. Judicial Activism: A Multidimensional Model. Canadian Journal of Law \& Jurisprudence, v. 18, n. 2, p. 333-356, 2005. Disponível em: < https://www.cambridge.org/core/journals/canadian-journal-of-law-andjurisprudence/article/judicial-activism-a-multidimensionalmodel/64E4FB896D67FFCB9A9F0ED749A972B9>. Acesso em 8 de novembro de 2020.

CORTES, Ana de Mello. Discriminação judicial por identidade de gênero: um diagnóstico. Revista Direito e Práxis, Rio de Janeiro, v. 10, n. 1, p. 101-128, 2019. Disponível em: $<$ http://www.scielo.br/scielo.php?script=sci_arttext\&pid=S2179$89662019000100101 \& \operatorname{lng}=$ en\&nrm=iso>. Acesso em 27 de outubro de 2020.

DAVIS, Angela Yvonne. Women, Race \& Class. Nova York: Randon House, 1983.

DINIZ, Maria Helena. Estado Atual do Biodireito. São Paulo: Saraiva, 2008.

DWORKIN, Ronald. Justice for Hedgehogs. Cambridge, Mass.: Harvard University Press, 2011

DWORKIN, Ronald. Taking Rights Seriously. 3rd edition. Cambridge, Mass.: Harvard University Press, 2002.

ELY, John Hart. Democracy and Distrust: a Theory of Judicial Review. Cambridge, Mass.: Harvard University Press, 1980. 
ENGEL, Cintia Liara. A violência contra a mulher. Brasília: IPEA, 2020. Disponível em: < https://www.ipea.gov.br/retrato/pdf/190215_tema_d_a_violenca_contra_mulher.pdf $>$. Acesso em 15 de outubro de 2020.

EPP, Charles. The Rights Revolution: Lawyers, Activists, and Supreme Courts in Comparative Perspective. Chicago: University of Chicago Press, 1998.

EPSTEIN, Lee. Some Thoughts on the Study of Judicial Behavior. William and Mary Law Review v. 57, n. 6, p. 2017-2073, 2017. Disponível em:

<https://scholarship.law.wm.edu/wmlr/vol57/iss6/3/Acesso em 10 de novembro de 2020.

ERICKSON-SCHROTH, Laura (Editor). Trans Bodies, Trans Selves: a Resource for the Transgender Community. New York: Oxford University Press, 2014.

FRASER, Nancy. Fortunes of Feminism. London: Verso, 2013

GONÇALVES, Luiz Carlos dos Santos. Mandados expressos de criminalização e a proteção de direitos fundamentais na Constituição brasileira de 1988. Belo Horizonte: Fórum, 2007.

HONNETH, Axel. The Struggle for Recognition: The Moral Grammar of Social Conflicts. Oxford: Polity, 1995.

HUNT, Lynn. Inventing Human Rights: A History. New York: W.W. Norton \& Company, 2007.

JEFFREYS, Sheila. Gender hurts: A Feminist analysis of the Politics of Transgenderism. New York: Routledge, 2014.

KECK, Thomas. Beyond Backlash: Assessing the Impact of Judicial Decisions on LGBT Rights. Law and Society Review v. 43, n. 1, p. 151-86, 2009. Disponível em:

<https://www.jstor.org/stable/29734174>. Acesso em 22 de agosto de 2020.

KMIEC, Keenan. Origin and current meanings of 'judicial activism'. California Law Review, v.92, n. 5, p.1441-1477, 2004. Disponível em: 〈https://www.jstor.org/stable/3481421〉. Acesso em 8 de novembro de 2020 .

KOERNER, Andrei. Ativismo Judicial?: Jurisprudência constitucional e política no STF pós-88. Novos estududos - CEBRAP, n. 96, p. 69-85, 2013. Disponível em: $<$ http://www.scielo.br/scielo.php?script=sci_arttext\&pid=S010133002013000200006\&lng=en\&nrm=iso>. Acesso em 8 de novembro de 2020.

LINS JÚNIOR, George Sarmento; MESQUITA, Lucas Isaac Soares. Neoconstitucionalismo ou Supremocracia? Uma análise do ativismo judicial no reconhecimento do nome social de pessoas trans na Ação Direta de Inconstitucionalidade n 4.275. Revista Direitos Fundamentais \& Democracia, v. 24, n. 1, p. 161-190, 2019. Disponível em: <https://revistaeletronicardfd.unibrasil.com.br/index.php/rdfd/article/view/1442/>. Acesso em 8 de novembro de 2020.

MELLO, Adriana. O Supremo Tribunal Federal e o Direito das Travestis à Unidade Prisional Feminina - Comentários à Decisão Proferida no Habeas Corpus nº 152.491. Direito em 
Movimento, Rio de Janeiro, v. 16 - n. 1, p. 193-211, $1^{\text {o }}$ sem. 2018. Disponível em:

<https://www.emerj.tjrj.jus.br/revistadireitoemovimento_online/edicoes/volume16_numero1/volu me16_numero1_193.pdf>. Acesso em 22 de agosto de 2020

MIARELLI, Mayra; LIMA, Rogério. Ativismo judicial e a efetivação de direitos no Supremo Tribunal Federal. Porto Alegre: Sergio Antonio Fabris, 2012.

OKIN, Susan Moller. Gênero, o público e o privado, o público e o privado. Revista Estudos Feministas, v. 16, 2, p. 305-332, 2008. Disponível em: <https://periodicos.ufsc.br/index.php/ref/article/view/S0104-026X2008000200002>. Acesso em 10 de novembro de 2020.

OLIVEIRA, José Wellington de et al. "Sabe a Minha Identidade? Nada a Ver com Genital": Vivências Travestis no Cárcere. Psicologia: Ciência e Profissão, v. 38, n. spe2, p. 159-174, 2018. Disponível em: <http://www.scielo.br/scielo.php?script=sci_arttext\&pid=S1414$98932018000600159 \& \operatorname{lng}=e n \& n r m=i s o>$. Acesso em 22 de agosto de 2020.

PHILLIPS, John. Transgender on Screen. New York: Palgrave Macmillan, 2006.

PERES, Ana Paula Ariston Barion. Transexualismo: o direito a uma nova identidade. Rio de Janeiro: Renovar, 2001

SCOTT, Joan. Gender and the Politics of History. New York: Columbia University Press, 1988.

SCUS [SUPREME COURT OF THE UNITED STATES]. Bostock v. Clayton County, Georgia. No. 17-1618; Altitude Express, Inc., et al., Petitioners v. Melissa Zarda and William Allen Moore, Jr., Co-Independent Executors of the Estate of Donald Zarda. No. 17-1623; R.G. \& G.R. Harris Funeral Homes, Inc., Petitioner v. Equal Employment Opportunity Commission, et al. No. 18-107. Argued October 8, 2019-Decided June 15, 2020. Disponível em:

<https://www.supremecourt.gov/search.aspx?filename=/docket/docketfiles/html/public/171618.html>. Acesso em 15 de outubro de 2020.

STEFANES PACHECO, Rosely Aparecida; STEFANES PACHECO, Isabela. Direito, violências e sexualidades: a transexualidade em um contexto de direitos. Estudios Socio-Jurídicos, v. 18, n. 2, p. 203-228, 2016. Disponível em:

<http://www.scielo.org.co/scielo.php?script=sci_arttext\&pid=S0124$05792016000200007 \& \operatorname{lng}=$ en\&nrm=iso>. Acesso em 27 de outubro de 2020.

TATE, Neal; VALLINDER, Torbnörn (Editors). The global expansion of Judicial Power. New York: New York University Press, 1995.

TAYLOR, Charles. Sources of the Self: The Making of the Modern Identity. Cambridge: Cambridge University Press, 1989.

TUSHNET, Mark. Taking the Constitution away from the Courts. Princeton: Princeton University Press, 1999.

USC [UNITED STATES CONGRESS]. Public Law No. 92-318, 78 Stat. 241, enacted July 2, 1964. Civil Rights Act of 1964. Disponível em: 
<https://www.govinfo.gov/content/pkg/STATUTE-78/pdf/STATUTE-78-Pg241.pdf>. Acesso em 15 de outubro de 2020

UPRIMNY, Rodrigo. Judicialization of Politics in Colombia: Cases, Merits and Risks. Sur: International Journal n. 6, p. 48-65, 2007. Disponível em:

$<$ https://sur.conectas.org/en/judicialization-politics-colombia/ >. Acesso em 8 de novembro de 2020 .

VECCHIATTI, Paulo Roberto. Constitucionalidade e Dever Constitucional da Classificação da Homofobia e da Transfobia como Crimes de Racismo. In: DIAS, Maria Berenice. Diversidade Sexual e Direito Homoafetivo. $3^{a}$ edição. São Paulo: Editora Revista dos Tribunais, 2017.

WEINBERG, George. Society and the healthy homosexual. New York: Saint Martin’s, 1972.

WILSON, Bruce; GIANELLA-MALCA, Camila. Overcoming the Limits of Legal Opportunity Structures: LGBT Rights' Divergent Paths in Costa Rica and Colombia. Latin American Politics and Society, v. 61, n. 2, 138-163, 2019. Disponível em:

<https://www.ca4.uscourts.gov/opinions/191952.P.pdf>. Acesso em 15 de outubro de 2020.

WILSON, Bruce. Institutional Reform and Rights Revolutions in Unlikely Places: Costa Rica and Colombia. Journal of Politics in Latin America, v. 1, n. 2, p. 59-85, 2009. Disponível em: $<$ https://journals.sagepub.com/doi/10.1177/1866802X0900100203>. Acesso em 8 de novembro de 2020.

YOUNG, Iris Marion. Justice and the Politics of Difference. New Jersey: Princeton University Press, 2011. 